\title{
Kolektif Başkanlık Teorisine Göre Yüksek Sovyet: İcra Kurulu Olarak Yüksek Sovyet Presidyumu ve Hükümet Organı Olarak Bakanlar Sovyeti
}

Av. Dr. Davut ÖZYURT*

Dr. Abdulkadir SAKA**

Makalenin Geliş Tarihi: 09.02.2021 Kabul Tarihi: 21.06.2021

Bu makale hakem incelemesinden geçmiştir ve TÜBİTAK - ULAKBİM Veri Tabanında indekslenmektedir.

DOI 10.30915/abd.978786

* Avukat, Ankara Barosu. https://orcid.org/0000-0001-8255-5234

** Arş. Gör. / Erciyes Üniversitesi Hukuk Fakültesi.

https://orcid.org/0000-0002-6919-4144 


\section{KOLEKTIF BAŞKANLIK TEORISINE GÖRE YÜKSEK SOVYET: ICRA KURULU OLARAK YÜKSEK SOVYET PRESIDYUMU VE HÜKÜMET ORGANI OLARAK BAKANLAR SOVYETI}

\section{ÖZ}

SSCB anayasal düzeni karma kuvvetler birliği ve kolektif başkanlık modelidir. Anayasal kuvvetler Yüksek Sovyet'te birleşmektedir. Yüksek Sovyet, devlet iktidarının yegâne kuvvetidir. Sovyet, Yüksek Sovyet Presidyumu ve Bakanlar Sovyeti olarak adlandırılan iki farklı kurum vasıtası ile fonksiyonlarını icra etmektedir. Yüksek Sovyet Presidyumu, sistemin kolektif başkanlık olarak adlandırılmasını sağlayan yapıdır. Bakanlar Sovyeti ise hükümet faaliyetlerini ifa etmektedir. Komünist Partisi doğrudan anayasal yetkiler bağlamında olmasa da parti üyelerinin Yüksek Sovyet, Yüksek Sovyet Presidyumu ve Bakanlar Sovyeti 'nde yerine getirdikleri görevler bağlamında oldukça önemlidir. Tüm bu ifade edilenlerin ışığında konu Yüksek Sovyet, Yüksek Sovyet Presidyumu ve Bakanlar Sovyeti'nin yap1sı, yetkileri ve fonksiyonları bakımından ele alınmıştır. Böylelikle Rusya Federasyonu'nun mevcut başkanlık modelinin gelişim evresi olarak ifade edilebilecek olan kolektif başkanlık modelinin anayasal kuvvetlerinin izah edilmesi amaçlanmıştır.

\section{Anahtar Kelimeler:}

Yüksek Sovyet

Bakanlar Sovyeti
Yüksek Sovyet Presidyumu

Sovyetler Birliği Komünist Partisi

Kolektif Başkanlık Hükümet Sistemi 


\title{
SUPREME SOVIET IN ACCORDING TO COLLECTIVE PRESIDENTIAL THEORY: PRESIDIUM OF THE SUPREME SOVIET AS EXECUTIVE BRANCH AND COUNCIL OF MINISTERS AS CABINET
}

\begin{abstract}
Constitutional order adopted by USSR is mix blended unification of Powers and collective presidency. The structure, performs its functions through two different institutions called Supreme SovietPresidium andthe Council of Ministers. Supreme SovietPresidium is structure that allows system to be called the collective presindency. Council of Ministers, implements goverment affairs. Communist Party is not directly in the context of constitutional powers, it has enormous importance in the context of the duties of party members in the Supreme Soviet, the Presidium Of the Supreme Soviet and Council Of Ministers. Therefore, it is aimed to explain the constitutional powers of the model of the Collective Presidency, which could be expressed as development era of the current presidential model of Russia.
\end{abstract}

\section{Keywords:}

Supreme Soviet Presidium of The Supreme Soviet

Council of Ministers Communist Party of The Soviet Union

Collective Presidential System of Governmant 


\section{A) GíRiş}

Rusya'da monarkın iktidarının sınırlandırılması ve anayasacılık hareketleri birçok ülkeden farklı serüvenlere konu olmuştur. Bugün kuvvetler ayrılığı teorisine göre şekillenmiş bir başkanlık sistemi bulunmasına karşın 76 yıllık Sovyet döneminin etki ve izlerini hala görmek mümkündür. Zira monarşinin ardından liberal temsili demokrasi tecrübesini yaşayan ülkelerin pratikleri ve kavram ile teorileri de bu minvalde doğrusal bir gelişim göstermiş iken Rusya'da araya Sovyet ideolojisi ve Sosyalist-Leninist çizgide gelişim gösteren farklı bir demokrasi anlayışının uygulaması girmiştir. Anayasa kavramının kendisinden, devlet iktidarının kuvvetlerine kadar her şey bu minvalde değerlendirilmiştir.

Temsil ve teşrii (kanun yapma) faaliyetine özgülenmiş bir parlamentonun varlığ1 reddedilmiştir. Bunun yerine hem bir parlamento hem de bir yürütme zümresi olarak Yüksek Sovyet ihdas edilmiştir. Yüksek Sovyet'in kendisi bizatihi bir temsil organıdır. En altta mahalli Sovyetler bulunmakta bunlar bir üst Sovyet'i oluşturmaktadır. Bu silsile bir piramit gibi ilerlemektedir. Piramidin en tepe noktasında ise Yüksek Sovyet bulunmaktadır. Sovyet ideologlar, bahse konu Sovyetlerin yapısından dolayı Yüksek Sovyeti batılı parlamentolardan ayırmaktadır. 1900'lü yılların başında hala dünyada monarşilerin güçlü olduğu dönemlerin var olduğu göz önüne alınır ise parlamentolar monarkın iktidarını sınırlandırma araçları olarak görülmektedir. Sovyet ideologlara göre ise bu durum, monarşinin başka usul altında yaşamasından başka bir şey değildir. Parlamentonun temsil vazifesi ise asli görevine giden yolda tali bir yol olarak görülmektedir. Tüm bunlara karş1lık Sovyetler iktidarın kendisidir. Bu iktidarın, halkın en minimal noktada temsili silsilesinden en tepeye uzanan organik bir noktada gerçekleştiğini iddia etmektedirler. Tüm bunlara rağmen teorinin altı doldurulurken ve uygulanırken Yüksek Sovyet bir parlamento vazifesi görmüş, bazı noktalarda ise bu vazifeyi de bihakkın yerine getirememiştir.

Yüksek Sovyet'in devasa yapısı göz önüne alındığında hem yürütme hem de yasama fonksiyonunu yerine getirmesinin ne kadar zor olacağı tahmin edilebilir. Kendi yapısal noksanlıkları da işin içine girince işletilmesi son derece zor bir form ortaya çıkmıştır. Bundan dolayı özellikle yürütme fonksiyonunun icrası için Yüksek Sovyet Presidyumu kurulmuştur. Bu Yüksek Sovyet'in daha ufak bir halinden başka bir şey değildir. Ancak Yüksek Sovyet yapısına göre farklılıklar oluşturularak meydana getirilmiştir. 
1930’lu yıllara gelindiğinde SSCB'nin birlik yapısı karmaşık bir hale gelmiştir. Bu kaotik yapısal durum içerisinde hem yasama hem de yürütme iş ve işlemlerini yöneten Yüksek Sovyet Presidyumu'nun yürütme fonksiyonu konusunda yaşadığı zafiyetlerin aşılabilmesi için Bakanlar Sovyeti kurulmuştur. SSCB'nin ilk döneminde Halkın Komiserleri olarak adlandırılan yapı üzerinde gerçekleştirilen reform ile kurulan Bakanlar Sovyeti, esasen bir kabine ve/veya hükümetten başka bir şey değildir. Sadece yürütme fonksiyonu için özgülenmiştir.

Sovyetler Birliği Komünist Partisi, anayasal anlamda hiçbir kuvvetin içinde zikredilmemesine, uzun yıllar Parti Genel Sekreteri' nin bir devlet görevinin dahi olmamasına rağmen son derece önemli ve kritik bir yapıdır. ${ }^{[1]}$ Formel olmasa bile fonksiyonel olarak bütün devlet ve yapı bu çekirdeğin etrafında şekillenmiştir.

Yüksek Sovyet, Yüksek Sovyet Presidyumu ve Bakanlar Sovyeti, uygulama içerisinde parlamento, başkan ve başbakan şeklinde ifade edilebilecek bir forma bürünmüştür. Biz bu çalışma içerisinde yapısal ve fonksiyonel anlamda bu kurumları izah ve tarif ederek okuyucunun zihninde kuvvetlerin nasıl ve ne şekilde çalıstığına dair idrakin kuvvetlenmesine çalışacağız.

\section{B) SSCB YÜKSEK SOVYETI}

Anayasal anlamda devlet iktidarının en yüksek organı olan Yüksek Sovyet ${ }^{[2]}$ esasen SSCB'nin yasama organıdır. SSCB yasama organı olarak Yüksek Sovyet, Birlik Sovyeti ve Milletler Sovyeti isimli iki kamaradan müteşekkil olup kamaraların eşit yetkileri bulunmaktadır. ${ }^{[3]}$ Bir totaliter sosyalist yapı olan SSCB'de parlamento üst kanadı, federatif yapıdan kaynaklı bölgesel temsil organı olarak işlev görmüştür. Çok katmanlı federatif yapının bir gereği olarak, bir temsil organının varlığının zaruri olmasından dolayı bu kamara ihdas edilmiştir. ${ }^{[4]}$

[1] Mesela LENIN'in tek vazifesi Komünist Parti Genel Sekreterliği'dir. SSCB içerisinde bunun dışında resmi bir görevi yoktur.

[2] Rusça bir kelime olan Sovyet, konsey anlamına gelmektedir. Detaylı bilgi için bkz; ÖZYURT, (Rus Tipi, 2021), S. 475, Dipnot 3.

[3] GRIPP, S. 213, UNGER, S. 94, SCHAPIRO, S. 109-110, CHKHIKVADZADE, S. 95.

[4] ÇİRKIN, (2013), S. 23. 
Yüksek Sovyet, SSCB'yi oluşturan halkın tamamına ait olan egemenlik yetkisini kullanan ve temsil eden mercidir. Yüksek Sovyet; Yüksek Sovyet Presidyumu üyelerini, Bakanlar Sovyeti üyelerini, Genel Savcıyı, Yüksek Mahkemeyi atar. Ayrıca diğer üst düzey devlet iktidarını kullanan organlara ilişkin atamaları da yapar. ${ }^{[5]}$

Yüksek Sovyet dört yıllığına; genel, eşit, gizli ve doğrudan oy prensipleri ile yapılan seçimle göreve gelir. Her iki kamaraya ilişkin seçimlerde eş zamanlı yapılır ve her iki kamarayı da halk seçer. ${ }^{[6]} 1966$ seçimlerinin ardında Birlik Sovyeti'nde 761, Milletler Sovyeti'nde 750 olmak üzere Yüksek Sovyet'te toplamda 1517 vekil bulunmaktadır. Birlik Sovyeti'nde yer alan her vekil yaklaşı 300.000 kişiyi temsil ederken, Milletler Sovyeti'nde ise federe unsurların her birisi farklı sayıda vekil ile temsil edilmektedir. ${ }^{[7]}$

Yüksek Sovyet üyeleri genel olarak Komünist Parti veya devlet görevlilerinden oluşmakta ve Yüksek Sovyet görevleri onların ikincil vazifeleri olmaktadır. Bunlar asli görevleri ile çok daha fazla meşguldür. ${ }^{[8]}$

\section{1) Yapısı}

Karma kuvvetler ve/veya kuvvetler birliği sistemini benimsemiş olan ${ }^{[9]}$ SSCB'de Yüksek Sovyet, devlet iktidarının en yüksek organı ${ }^{[10]}$ olup Milletler Sovyeti ve Birlik Sovyeti adında iki kanadı olan bir parlamentoya karşılık gelmektedir14. Birlik Sovyeti, Birliğin tamamındaki halkı temsil eder iken Milletler Sovyeti, federe unsurların temsil organıdır. ${ }^{[1]}$

Kuvvetler ayrılığının kabul göremediği Sovyet anayasal düzeni gereği; Yüksek Sovyet, yasama ve yürütme kuvvetinin yetkilerine de sahiptir. SSCB Yüksek Sovyeti, demokratik temsilin en alt tabakasından en üst noktasına kadar olan Sovyetlerin, en tepesinde yer almaktadır. ${ }^{[12]}$ Diğer yan-

[5] CHKHIKVADZADE, S. 95-100, STEŞANKO, S. 267-269.

[6] CHKHIKVADZADE, S. 95-104.

[7] GRIPP, S. 213, UNGER, S. 94, CHKHIKVADZADE, S. 95

[8] SCHAPIRO, S. 115.

[9] ÖZYURT, (Rus Tipi, 2021), S. 4-7.

[10] SSCB'nin 1936 tarihli Anayasası'nın 30. maddesi ve 1977 tarihli Anayasası'nın 108. maddesi.

[11] SSCB'nin 1936 tarihli Anayasası'nın 33. maddesi ve 1977 tarihli Anayasası'nın 109. maddesi.

[12] TANİLLI, S.201 
dan, devlet iktidarını kullanan tüm organları sarmalamaktadır. ${ }^{[13]}$ Diğer yandan, devlet iktidarını kullanan tüm organları sarmalamaktadır. ${ }^{[14]}$

Daha önce de ifade ettiğimiz üzere Milletler Sovyeti, SSCB'nin federal yapısının bir gereği olarak ortaya çıkmış olup ABD'deki Senato'ya benzer bir görev ifa etmiştir. Milletler Sovyeti, SSCB'yi meydana getiren federe unsurların temsilcilerinden oluşmaktadır. 1936 tarihli Anayasa'nın 35. Maddesine göre Milletler Sovyeti'nde her Birlik Cumhuriyeti 25, her Özerk Cumhuriyet 11, her Otonom Bölge 5 ve her Ulusal Alan 1 temsilci ile temsil edilmektedir. 1977 tarihli Anayasa’nın 110. Maddesine göre Milletler Sovyeti'nde her Birlik Cumhuriyeti 32, her Özerk Cumhuriyet 11, her Otonom Bölge 5 ve her Otonom Alan 1 temsilci ile temsil edilmektedir.

ABD'deki Temsilciler Meclisi'ne benzeyen Birlik Sovyeti, 1936 tarihli SSCB Anayasası'nın 33. Maddesine göre her 300.000 kişiyi temsilen bir milletvekili seçilmesi ile oluşmaktadır. 1977 tarihli Anayasa, rakamsal olarak kaç kişinin bir milletvekili tarafından temsil edileceğini düzenlememiştir. Bununla birlikte 110. Maddesine göre nüfus oranına nispetle belirlenecek seçim bölgelerinden temsilciler seçileceğini ifade etmiş ve Birlik Sovyeti'nin temsilci sayısının Milletler Sovyeti ile aynı olacağını da belirtmiştir. Böylelikle Yüksek Sovyet'in toplam üye sayısı 1500'e ulaşmışırı. Yüksek Sovyet vekilleri, vekil olmaktan ötürü maaş alamamaktadır. Ancak sayısız tür ve ad altında devlet yardımlarından faydalanmaktadırlar. Vekillik için asgari yaş 23 olarak düzenlenmiş daha sonra 21 'e düşürülmüştür. ${ }^{[15]}$

1977 tarihli Anayasảnın Seçim Sistemi Başlıklı Bölümü’nün altında yer alan 95. Maddesine göre Yüksek Sovyet'in her iki kanadına ilişkin yapılacak seçimler eşit, genel, gizli oy esaslarına göre yapılmak zorundadır. 18 yaşını doldurmuş olan her SSCB vatandaşı seçme yeterliliğine sahip olmakta, 21 yaşına doldurmuş SSCB vatandaşları ise seçilme yeterliliğine haiz olmaktadır. Seçimler 5 yılda bir iki turlu ve dar bölge çoğunluk sistemi usullerine göre yapılmaktadır. ${ }^{[16]}$

[13] 16 REMINGTON, S. 23, KIRICHENKO/DENISOV, S. 315, ÇİRKIN, (2013), S.66.

[14] TOWSTER, S. 318.

[15] GRIPP, S. 230, KIRICHENKO/DENISOV, S. 315, STEŞANKO/ŞAMBA, S. 267-269.

[16] CHKHIKVADZADE, S. 95-100, KIRICHENKO/DENISOV, S. 315. 
1977 tarihli SSCB Anayasası' nın 100. Maddesine göre seçimlerde aday gösterme hakkı SBKP, ticari birlikler, Komsomoller ${ }^{[17]}$, kooperatif, sendika ve diğer toplumsal örgütlenmeler arasında paylaştırılmıştır. Buna karşın SSCB'nin bir "Parti Devleti” olduğu göz önünde bulundurulursa, seçimlerde aday gösterme tekelinin SBKP lehine oluştuğunu ifade etmek yanlış olmayacaktır. Seçimler her ne kadar gizli, serbest ve genel oy ilkelerine uygun bir biçimde gerçekleştirilse dahi, aday göstermek için SBKP'nin iradesi dışına çıkmanın pek de mümkün olmayışı nedeniyle, SSCB'de seçimlerin göstermelik olduğu eleştirisi yapılmıştır. ${ }^{[18]}$

Liberal temsili demokrasi ideal ve arzusu olmayan SSCB'de, seçimler daha ziyade SSCB vatandaşları ile SBKP'nin bir iletişim vasıtası olarak görülmektedir. SBKP, iç ve dış siyasi politikalarını halka anlatmakta ve halkı siyasi olarak eğitmektedir. SSCB'nin halk tarafından seçilmiş meşru bir yasama ve yürütme kuvvetinden teşekkül ettiğinin iç ve dış kamuoyuna duyurulması da seçimler vesilesi ile olmaktadır. ${ }^{[19]}$

\section{2) Oturumları ve Komisyonları}

Yüksek Sovyeti oluşturan her iki kamara da aynı dönemde Moskova'da Kremlin Sarayı'nda toplanmaktadir. ${ }^{[20]}$

Yüksek Sovyet, sürekli oturum gerçekleştiren ve sürekli açı olan bir parlamento değildir. Üstelik Yüksek Sovyet, faaliyet ve oturumları kamuya da açık değildir. 1936 Anayasası'nın 36. Maddesine ve 1977 Anayasası'nın 112. Maddesine göre Yüksek Sovyet yılda iki kere toplanmaktadır. Parlamento'nun her iki kanadı da aynı anda toplanmakta ve dağılmaktadır. Bu toplantılar yılda iki defa olmak üzere, birkaç günlüğüne yapılmaktadır. Olağan oturumlara çağrı Yüksek Sovyet Presidyumu tarafından yapılmaktadır. Olağanüstü oturumlar ise Birlik Cumhuriyetlerinin talebi ile veya re'sen, Yüksek Sovyet Presidyumu tarafından yapılabilmektedir. Yüksek Sovyet Genel Kurul oturumları, en yaşlı üye tarafında açılmakta, oturumları Yüksek Sovyet Başkanı ve dört yardımcısı yönetmektedir. Toplanma dönemlerinde oturumlar saat 11:00-15:00 ve 18:00-22:00 saatleri

[17] Leninist Komünist Gençler Birliği'ni ifade etmek için Komsomol ifadesi kullanılmaktadır. Bahse konu birlik, 1977 tarihli SSCB Anayasası'nın 7. maddesi ile koruma altına alınmış bir gençlik teşekkülüdür.

[18] ÇAM, S. 237, KIRICHENKO/DENISOV, S. 315

[19] ÇAM, S. 237, SCHAPIRO, S. 114.

[20] CHKHIKVADZADE, S. 106-108. 
arasında hafta sonu da dahil her gün yapılmaktadır. Yüksek Sovyet Genel Kurul oturumlarında, Yüksek Sovyet Presidyumu'nun kararnameleri onaylanmaktadır. Genellikle bu oylamalar yazılı usul ile değil, el kaldırma ve bu suretle reylerin sayılması yolu ile yapılmaktadır. ${ }^{[21]}$

Yüksek Sovyet' in yılda iki defa olmak üzere her defasında 10 günü geçmeyecek şekilde yaptığı oturum ve toplantılarda zamanın önemli bir kıs$\mathrm{m}$, raporların okunması ile geçmektedir. Yasama faaliyeti bakımından yılda ortalama 10 kanun yapılmakta, her oturumda ise en fazla 5 tasarı veya teklif kanunlaşabilmektedir. Aynı dönemlerde dünyanın diğer ülkelerinde ise yasama organları yılda ortalama 100 kanun yapmaktadır. Çoğu örnekte görüldüğü üzere Yüksek Sovyet Presidyumu'nun -Yüksek Sovyet'in oturum yapılmadığı dönemlerde- yaptığı düzenleyici işlemler Yüksek Sovyet'te kanunlaşmaktadır. ${ }^{[2]}$ Yani Yüksek Sovyet, kendisi kanun yapım faaliyet ve görevini yerine getirememektedir.

Yüksek Sovyet' in gerek üye sayısının çok fazla olması gerekse yılda ancak iki kere toplanıyor olmasından dolayı işlevsel olarak, rakibi olan liberal temsili demokrasilerdeki meclislerden daha işlevsel olmayı başaramadığ aşikârdır. Yüksek Sovyet oturumları, Bakanlar Sovyeti ve Yüksek Sovyet Presidyumu kararlarının onaylanmasından öteye hiçbir zaman geçememiştir. $^{[23]}$

Her ne kadar kanun yapma yetkisinin aslen Yüksek Sovyet'te olduğu anayasal olarak belirtilmiş olsa da daimî faaliyet göstermeyen ve sürekli açı olmayan Yüksek Sovyet'in kanun yapma iradesini ortaya koyamadığı bir gerçektir. Bundan ötürü Yüksek Sovyet Presidyumu ve Bakanlar Sovyeti' nin düzenleyici işlemleri çoğu zaman bir kanun yapma faaliyeti ile özdeş olmuştur. Esas kanun yapıcı organın Yüksek Sovyet Presidyumu ve Bakanlar Sovyeti olduğunu ifade eder isek yanlış bir tespit yapmıs olmayız. Zira Yüksek Sovyet devasa bir yapıdır. Böylesi bir yapının fiili ve fonksiyonel olarak yasama faaliyetini icra edebileceğini savunmak çok güçtür.

Yüksek Sovyet Genel Kurulu’nun 1962 yılındaki oturumu 10 Aralık ve 13 Aralık tarihlerinde toplam 4 günlük bir sürede gerçekleşmiştir. 2 gün 1963 bütçesine ilişkin görüş, öneri ve tartışmalar ile geçmiştir. Diğer 2 gün

[21] GRIPP, S. 217.

[22] GRIPP, S. 224.

[23] REMINGTON, S. 24, CHKHIKVADZADE, S. 95-113, ÇİRKİN, (2015), S. 132. 
ise dış politikaya dair görüş, öneri ve tartışmalar ile geçmiştir. 4. yani son günün bir kısmında Yüksek Sovyet Presidyumu'nun bir dizi kararnamesi onaylanarak kanun haline getirilmiştir: 10 adet kararname Anayasa’nın 3. Maddesinde değişiklik yapılmasını gerektirmiş, 14 kararname geçmiş altı aylık döneme ilişkin bakanlık atamaları ile ilgili olmuş, 4 kararname askerlik servisi ve vergiler ile ilgili hükümler içermiştir. Bunlardan hiçbirisine ilişkin gerçek veya göstermelik bir tartışma yaşanmamıştır. ${ }^{[24]}$

Yüksek Sovyet, fonksiyonel olarak yasama işlemlerinin onay ve deklarasyon makamı olarak görülmüştür. Gerçekte ise yasama faaliyetleri SBKP tarafından yönetilmiştir. Parti'nin, SSCB'nin hukuki ve kanuni iş ve işlemlerini takip ve tayin eden oldukça dar kapsamlı ve eğitimli bir kadrosu bulunmaktadır. Ayrıca parti bu anlamda Bakanlar Sovyeti ile de iş birliği içerisindedir. Gerçekten de önemli sayılabilecek kanuni düzenlemelere baktığımız zaman bunların Bakanlar Sovyeti ve SBKP Merkezi Komitesi tarafından deklare edilmiş, çok daha sonra ise Yüksek Sovyet tarafından kanun olarak kabul edilmiş olduğunu görebiliyoruz. Bu ve buna benzer örneklerden dolayı Yüksek Sovyet bir yasama organı olmaktan uzak görülerek "kabul komisyonu" [25], "lastik damgadan" [26] bir onay makamı olmakla eleştirilmiştir.

Yüksek Sovyet, olağan üstü toplantılar haricinde Yüksek Sovyet Presidyumu tarafından yapılan çağrı ile veya re'sen yılda iki defa toplanmaktadır. Bu toplanma süreleri ise bir hafta veya on günü geçmemektedir. Iş̧te bu sebepten ötürü Yüksek Sovyet’ in "göstermelik bir yasama organı olduğu" yönünde eleştiriler yer almaktadır. Gerçekten de devlet politikasını üretmek, Bakanlar Konseyi'ni denetlemek ve kanunlaştırma yapmak gibi önemli ve zaman alan işlerin böylesi bir usul ile gerçekleştirilmesi imkânı bulunmadığı açıktır. Kanaatimizce Anayasa her ne kadar Yüksek Sovyet'e "yasama tekeli” vermiş olsa dahi fiiliyatta bunun hiçbir anlamı bulunmamaktadır. Yüksek Sovyet fonksiyonel ve anlamlı bir organ olmaktan çok uzaktır. ${ }^{[27]}$

Sovyet demokrasi anlayışı üzerine inşa edilen anayasal sistemin canlandırılabilmesi adına STALINN sonrası dönemde de birtakım gelişmeler daha yürürlüğe sokulmuştur. Bunlardan belki de en önemlisi Yüksek Sovyet'in

\footnotetext{
[24] SCHAPIRO, S. 113.

[25] SCHAPIRO, S. 113.

[26] BRAHAM, S. 309.

[27] UNGER, S. 96, SCHAPIRO, S. 112-113.
} 
daimî komisyonlarıdır. ${ }^{[28]}$ Yüksek Sovyet'in yılın belirli zamanlarında faaliyet göstermesi nedeniyle işlevsiz kalmaması adına Yüksek Sovyet' in oturum düzenlemediği dönem içerisinde de Yüksek Sovyet nam ve hesabına faaliyet yürüten organlar olarak daimî komisyonlar kurulmuştur. 1938 yılında Yüksek Sovyet, anayasal yetkilerine dayanarak üç farklı daimî komisyon kurma kararı almıştır. Bunlar yasama komisyonu, bütçe komisyonu ve dış ilişkiler komisyonudur. 1957 yılında Milletler Sovyeti tarafından ekonomi komisyonu kurulmuştur. 1966 yılında Yüksek Sovyet' in her iki kanadında da faaliyet göstermek üzere 16'şar komisyon kurulmuştur. Bunar tarım, endüstri, inşaat, ticaret ve kamu servisi, eğitim, sağlık ve sosyal refah gibi alanlarda faaliyet yürütmeyi amaçlamıştır. ${ }^{[29]}$

Kısacası oldukça kısa süre için toplanan Yüksek Sovyet'in herhangi bir şeyi tartışmaya hazırlamak için yeterli zamanı yoktur. Bu sebeple daimî komisyonlar "hazırlık" çalışmalarını yapmak için kurulmuştur. Daimî komisyonlardan alınan fayda sebebiyle başlangıçta dört olan daimî komisyon sayısı zamanla arttırılmıştır. Dahası 12 Ekim 1967'de daimî komisyonların yasal statüsü ile ilgili düzenleme yapılarak yetkileri arttırılmış ve üyeleri için önemli sayılabilecek yetkiler tanımlanmıştır. ${ }^{[30]}$

1967 yılında Yüksek Sovyet'in Milletler Sovyeti ve Birlik Sovyeti adl 1 kamaralına bağlı daimî komisyonlarının Yüksek Sovyet Presidyumu tarafından "koordine" edileceği kararlaştırılarak, bu komisyonların varlık gayelerinin; Yüksek Sovyet'in oturum dönemlerinde tartışılacak ve görüşülecek kanun taslaklarını hazırlamak ve devletin idari bölümlenmelerinde ki faaliyetlerin denetimi olacağı da hüküm altına alınmıştır. ${ }^{[1]}$

Yüksek Sovyet'in her iki kamarası da genellikle faaliyetlerini daimî ve geçici komisyonlar vasıtası ile görmektedirler. Her iki komisyonda da bulunan Yasama Komisyonu en önemli komisyondur. Daimî bir komisyon olan Yasama Komisyonu, Yüksek Sovyet Genel Kurulu'nun toplanmadığ 1 dönemlerde faaliyetlerini sürdürmekte ve Presidyum ile koordine kurmaktadır. ${ }^{[32]}$ Kanun teklifleri bakımından her iki kamaranın da daimî komisyonları faal bir şekilde çalışmaktadır. ${ }^{[33]}$

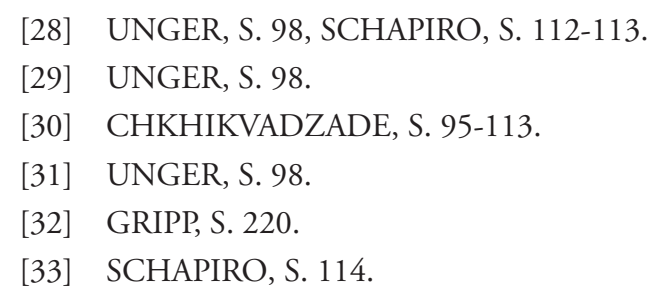


Daimî komisyonlar, kamaraların yardımcı hazırlık organları olarak tarif edilmektedir. Ayrıca bakanlıkları ve diğer organları kontrol görevi de üstlenmektedirler. Çalışmaları ile ilgili hazırladıkları nihai raporlar, ilgili kamara tarafından oturumlarda kullanılmakta ve çoğu zaman esas alınmaktadır. Her daimî komisyon, çalışmaları ile ilgili olarak bağlı bulunduğu Yüksek Sovyet kamarasına sorumlu olup faaliyetleri Yüksek Sovyet Presidyumu tarafından "koordine" edilmektedir. ${ }^{[34]}$

Kanun Teklif Komisyonu; kanun yapımı değiştirilmesi ve anayasa değişikliklerinden sorumlu olan daimî komisyondur. Bir diğer önemli komisyon ise her iki kamarada da bulunan bütçe komisyonlarıdır. Plan ve Bütçe Komisyonu; 51 üyeli daimî bir komisyondur. Uzun dönem iktisadi planlar ve yıllık bütçeyi hazırlamak ile mesuldür. Ayrıca cari yılın bütçesinin nasıl kullanıldığını denetlemek de asli görevleri arasındadır. Yıllık bütçe planları bütçe komisyonlarının ortak toplantılarında hazırlanmaktadır. Ayrıca bütçe komisyonunun; Temel Plan Göstergeleri, Devlet Gelirleri gibi alt komisyonları da bulunmaktadır. Bilahare zaman zaman bakanlıkların veya federe unsurların faaliyetlerinin denetimi için de daimî komiteler kurulduğu olmuştur. ${ }^{[35]}$

Dış İlişkiler Komitesi; SSCB'nin milletlerarası alandaki faaliyetlerini denetlemek ve gözlemlemek ile mesul olan daimî bir komisyondur. Milletlerarası ilişkiler anlamında hazırlanması gereken kanun teklifleri ve diğer görüşler için de hazırlık yapmaktadır. Gençlik Komitesi, genç neslin Sovyet ideolojisi ile yetiştirilmesi için çalışma yapan daimî komisyondur. Sektörel Daimî Komisyonlar, iktisadi değişimlerin takibi ve bunlara ayak uydurulması amacıyla kurulmuştur. Endüstri, Taşımacılık ve İletişim, İnşa ve Endüstriyel Materyalleri, Tarım, Sağlık ve Sosyal Güvenlik, Ticaret, Tüketim ve Komünel Servis ve Tabiatın Korunması; Eğitim, Bilim ve Kültür adı altında sayılacak olanlarla birlikte toplamda 552 sektörel daimî komisyon bulunmaktadır. ${ }^{[36]}$

\section{3) Yetkileri}

Yüksek Sovyet'in anayasal yetkileri belirsiz ve geniştir. Savaş ve barış işlerinin icrası, askeri işler, milli ekonomik planın oluşturulması, bütçenin tayin edilmesi, federal sınırların tayini, ceza hukuku, medeni hukuk, aile

[34] CHKHIKVADZADE, S. 95-114.

[35] GRIPP, S. 221-222, CHKHIKVADZADE, S. 115-118.

[36] CHKHIKVADZADE, S. 119-123. 
hukukunun temel ilkelerinin belirlenmesi, doğal kaynakların kullanılması konularında Yüksek Sovyet tek yetkilidir. ${ }^{[37]}$

SSCB Anayasası'nı değiştirmek, kanun yapmak, bütçeyi onaylamak, Birliğe yeni cumhuriyetlerin katılmasını kabul etmek Yüksek Sovyet'in önemli yetkileri arasında sayılmaktadır. 1936 tarihli Anayasa’nın 36. Maddesi ve 1977 tarihli Anayasa’nın 109. Maddesine göre Yüksek Sovyet'in her iki kanadı da yetkiler bakımından eşittir. Yüksek Sovyet'in her iki kanadı da kanun tasarısı sunabilmektedir. Ayrıca Yüksek Sovyet Presidyumu, Bakanlar Sovyeti, Yüksek Mahkeme, Birlik Genel Savcısı da kanun tasarısı sunabilmektedir.

Kanun tasarıları, Yüksek Sovyet'in her iki kanadında da ayrı ayrı görüşülmektedir. Her kanat kendi üye sayısının salt çoğunluğu ile kanun tasarısını kabul eder ise tasarı kabul edilmiş olmaktadır. 1977 Anayasası'na kadar kanun yapmak dâhil diğer tüm kararlar için her kamarada basit çoğunluk karar yeter sayısı olarak kâfidir. ${ }^{[38]} 1977$ Anayasası kanunlar için mutlak çoğunluğu öngörerek diğer yasama işlem ve kararlarını kanunlardan ayırmıştır.

Kamaralar arasında ortaya çıkan anlaşmazlık durumunda; her iki kamaranın eşit sayıda temsilcisinin hazır bulunduğu bir uzlaşma komisyonu kurulmaktadır. Eğer uzlaşma komisyonunda ortaya bir uzlaşma çıkmaz ise ihtilaf konusu, her iki kamarada tekrar oylanmaktadır. 1977 Anayasası'ndan önceki uygulamada, eğer yine ortada bir ihtilaf bulunur ise Yüksek Sovyet Presidyumu, Yüksek Sovyeti feshederek yeni seçim tarihini belirlemektedir. 1977 Anayasası ile çözülemeyen ihtilaf reddedilmişs sayılmakta ve Yüksek Sovyet' in feshi söz konusu olmamaktadır. ${ }^{[39]}$

Yüksek Sovyet' in çıkardığı kanunlar ile Bakanlar Kurulu'nun düzenleyici işlemlerinin sayı olarak karşılaştırılması dahi mümkün olamamaktadır. Yüksek Sovyet, yılda en fazla 20 kanun çıkarabilmekte iken, Bakanlar Kurulu'nun düzenleyici işlemlerinin sayıs 15.000'i geçmektedir. Bakanlar Kurulu' nun düzenleyici işlemlerinin bir üst norma uygunluğunu denetleyecek herhangi bir kurum da öngörülmemiştir. Tüm bunların neticesinde tabii olarak, yasama ve yürütme organlarının tüm yetkilerini taşıyan güçlü bir Yüksek Sovyet'ten -anayasal olarak bahsedilse dahi- pratikte söz etmek

[37] GRIPP, S. 217, CHKHIKVADZADE, S. 95-100.

[38] SCHAPIRO, S. 110.

[39] SCHAPIRO, S. 110. 
imkânı yoktur. ${ }^{[40]}$

Yüksek Sovyet' in denetim, gözetim ve kontrol yetkisi; 1977 Anayasası'na kadar örtülü kalmış, açıkça düzenlenmemiştir. 1977 Anayasası'nın 126. Maddesi ile Yüksek Sovyet'in devlet organlarını denetleyebileceği ve bu denetimin nasıl olacağ a açıkça ortaya konmuştur. Ayrıca 1965 'te kurulan Halkın Kontrol Komitesi de anayasal bir organ haline getirilmiştir. Parti ve hükümetin direktifi ile faaliyet gösteren Halkın Kontrol Komitesi, görevi ve denetimleri ile ilgili olarak Sovyetlere bilgi vermektir. Halkın Kontrol Komitesi, sivil gönüllü müfettişlerden oluşmakta olup sayısı 1980'lere gelindiğinde 10.000.000'un üzerindedir. ${ }^{[41]}$ İşte bu kurum 1977 Anayasası ile birlikte Yüksek Sovyet'e bağlanmıştır. Halkın Kontrol Komitesi artık Yüksek Sovyet ve Yüksek Sovyet Presidyumu'nun denetim aracına dönüşmüştür.

\section{C) SSCB YÜKSEK SOVYET PRESIDYUMU}

Yüksek Sovyet'in sürekli oturum gerçekleştiren bir parlamento olmamasından dolayı Yüksek Sovyet'in toplantı dönemleri haricinde onun görevlerini ifa edecek bir kurum olarak Yüksek Sovyet Presidyumu teşkil edilmiştir. ${ }^{[42]}$ Temel olarak Yüksek Sovyet Presidyumu yasama ve yürütme yetkileri kullanan anayasal bir organdır. ${ }^{[43]}$ Yüksek Sovyet Presidyumu, Yüksek Sovyet'in daimî faaliyet gösteren organı ${ }^{[44]}$ olarak Yüksek Sovyet oturum dönemleri arasında gerçekleştirdiği bütün işlemlerden Yüksek Sovyet'e bilgi vermek zorundadır. Devlet idaresinin sürekliliğinin bir gereği olarak ortaya çıkmıstır. Devlet iktidarının en yüksek organının faaliyetlerinin daimî olmasını sağlamaktadır. Bu minvalde Yüksek Sovyet oturumları arasında devlet iktidarının en üst temsilcisi Yüksek Sovyet Presidyumu'dur. ${ }^{[45]}$ Diğer yandan Yüksek Sovyet Presidyumu, devlet iktidarını daimî olarak kullanan Yüksek Sovyet' in kontrolündeki en yüksek devlet iktidarı organıdır. Aslında Yüksek Sovyet Presidyumu, Yüksek Sovyet' in fonksiyonunu üstlenmektedir. ${ }^{[46]}$

\footnotetext{
[40] HUSKEY, S. 84-91, POPOV/MİGRAÇEV/TİHOMİROV, (2012), S. 105.

[41] UNGER, S. 98.

[42] GÜRBÜZ, S. 182.

[43] SCHAPIRO, S. 111.

[44] KUTAFIN, S. 217.

[45] CHKHIKVADZADE, S. 124-129, KUTAFIN, S. 219-220.

[46] KUTAFIN, S. 221.
} 
Faaliyetleri Yüksek Sovyet tarafından kontrol edilen Yüksek Sovyet Presidyumu tabii olarak Yüksek Sovyet'e karşı sorumludur. Yüksek Sovyet oturumlarının arasındaki dönemde Bakanlar Sovyeti ise, Yüksek Sovyet Presidyumu'na karşı sorumludur. Yüksek Sovyet' in her iki kamarasının ortak oturumunda yapılan seçimle iş başına gelen Yüksek Sovyet Presidyumu, kolektif karaktere sahiptir. ${ }^{[47]}$

1936 Anayasası oluşturulurken Yüksek Sovyet Presidyumu Başkanı’nın doğrudan halk tarafından seçilmesine ilişkin önemli bir öneri verilmiştir. Yüksek Sovyet' in iktidarına karşlık bir başka iktidarın daha baş gösterecek olmasının Sovyet ideolojisi ile ve bu anlamda kolektif başkanlık anlayışı ile çelişeceği gerekçeleri ile STALİN tarafindan bu öneri şiddetle reddedilmiştir. Böylelikle Yüksek Sovyet Presidyum Başkanı’nın, Yüksek Sovyet tarafından seçilmesi yönünde bir düzenleme yapılmıştır. ${ }^{[48]}$ Dahası SSCB Başkanlığı 1936 Anayasası'nın taslak metninde olmasına karşın STALİN tarafından benzer maksatlar ile metinden çıkarılmıştır. ${ }^{[49]}$

Esasen Sovyet ideolojisi tarafindan "burjuva demokrasi" olarak ifade edilen liberal temsili demokrasiye ait bir tabir ve terim olduğu için -her ne kadar ihtiyaç olsa dahi- başkanlık kurumunu ihdas edemeyen Sovyet ideolog ve hukukçuları, Yüksek Sovyet Presidyumu'nu bir "Sovyet Başkanlık" kurumu olarak konumlandırmaya çalışmıslardır. Yüksek Sovyet Presidyumu, kurumsal ve kolektif olarak devlet başkanlığ görevini üstlenmektedir. Tek kişiden oluşmayıp kolejyal bir yapı olması da onu özgün ve "sosyalist" yapmakta, yani Sovyet anayasa hukukçularının tabiri ile "burjuva demokrasi" modelinden ayırmaktadır. ${ }^{[50]}$ Bu kapsamda sosyalist kamu hukukçusu olan MUHAMEDOVA'nın açıklamaları konuyu güzel bir biçimde özetlemektedir. Yazara göre Yüksek Sovyet Presidyumu, sosyalist ülkelerdeki başkanlık idaresidir. Ancak sadece devlet başkanlığı fonksiyonunu içermez, bütün devlet iktidarını kullanmaya yetkilidir. "Burjuva demokrasilerdeki" parlamento ve hükümet yetkileri burada birleşmektedir. Ancak burada en önemli husus şudur: Yüksek Sovyet yasama yetkilerini devretmemekte ya da paylaşmamaktadır. Yüksek Sovyet Presidyumu bahse konu yetkilerini Yüksek Sovyet adına ve ona karşı sorumlu olarak kullanmaktadır. ${ }^{[1]}$ Diğer

[47] CHKHIKVADZADE, S. 124-129, KUTAFIN, S. 219.

[48] TOWSTER, S. 321, LAZAREV, S. 10.

[49] LAZAREV, S. 10, STEPHEN, S. 72.

[50] ÖZYURT, (Rus Tipi, 2021), S. 4-9, KUTAFİN, S. 226-230.

[51] MUHAMEDOVA, S. 17-19. 
yandan ne hukuki olarak ne de siyasi olarak hiçbir metinde resmi, formel biçimde Yüksek Sovyet Presidyumu'nun devletin başı olduğuna dair bir ibare ile karşılaşmak da mümkün değildir. ${ }^{[52]}$

Daha önce ifade edildiği üzere Yüksek Sovyet Presidyumu Sovyet yazarlarına göre kolejyal bir başkanlıktır. Yüksek Sovyet Presidyumu, SSCB’nin kolektif başkanlık nizamını temsil etmektedir. Yüksek Sovyet Presidyumu için sürekli faaliyette olan en yüksek devlet organı ifadesi kasıtlı olarak kullanılmaktadır. Ayrıca Yüksek Sovyet'in iki kamarasının faaliyetlerinin tek elde toplanması ve birleştirilmesi noktasında da faaliyet göstermektedir. ${ }^{[53]}$ Tüm bunların ışığında SSCB'nin siyasi sistemi içerisinde "Başkanlık" adı verilen bir kurum bulunmamakla birlikte Presidyumu liberal temsili demokrasilerdeki "Devlet Başkanı' na” benzetmek çok da yanlış olmayacaktır. ${ }^{[5]]}$ Zira Presidyum Başkanı'nın sahip olduğu yetkiler, devlet başkanına eş olarak değerlendirilebilecektir. Sovyet hukukçularının ifadesi ile bu bir "kolejyal başkanlık" olarak algılanmalıdır. ${ }^{[5]}$ Diğer yandan başkanlık sistemlerindekinden farklı olarak karma kuvvetler birliği veya kuvvetler birliği modelinin açı bir gereği olarak yasama yetkilerinin önemli bir kısmını da elinde bulundurmaktadır.

1977 Anayasası ile birlikte Sovyetler Birliği Komünist Parti Genel Sekreteri, Yüksek Sovyet Presidyumu Başkanı olarak görev yapmaya başlamıştır. Daha önce SSCB'nin “resmi olmayan lideri”, zımnen Sovyetler Birliği Komünist Parti Genel Sekreteri olarak görülüyor ve kabul ediliyor ancak bu durum anayasal bir hale getirilmiyordu. Böylesi bir "boşluk" ise özellikle karşılaştırmalı hukuk bağlamında Sovyet anayasa hukukçularını zora sokuyor, iç hukuk kapsamında ise LENIN ve STALINN kadar "güçlü" olamayan liderlerin devlet iktidarı üzerindeki etkilerini kısıllıyor veya bu kimselerin "dolaylı" hareket etmek zorunda kalmasına yol açıyordu. 1977 Anayasası ile bu noksanlık giderilemeye çalışılmıştır.

Sovyetler Birliği Komünist Parti Genel Sekreteri'nin aynı zamanda Yüksek Sovyet Presidyumu Başkanı olmasına ilişkin itirazlar klasik SSCB bakış açısından kaynaklanmakta idi. Bahse konu makamların her ikisinde de aynı kişilerin bulunması "başkanlık" olarak algılanmakta ve buna karşı

[52] KUTAFIN, S. 226-230.

[53] GRIPP, S. 215.

[54] HENDERSON, S. 35-42.

[55] UNGER, S. 100, KUTAFIN, S. 219. 
çıkılmakta idi. Zaruret halinden kaynaklanmış olsa dahi bahse konu itirazın aşılabilmesi için Yüksek Sovyet Presidyumu Başkanı'na münhasır yetkiler verilmek yerine Yüksek Sovyet Presidyumu Başkanlık Ofisi'ne anayasal yetki tanımlaması yapılmış, böylelikle "kolektif başkanlık" olarak ifade edilen prensip korunmaya çalışılmıştır. Yüksek Sovyet Presidyumu Başkanı Birinci Yardımcılığının oluşturulması da aynı sebeplere dayanmıştır. ${ }^{[56]}$

Ancak çalışmamızın devamında göreceğimiz üzere, Sovyet ideolog ve hukukçuları "kolejyal" bir başkanlık modelini başarı ile oluşturamamışlardır. Bundan ötürü her anayasa değişikliği dönemindeki tartışmalarda "tek kişiden müteşekkil bir başkanlık” müessesesi kurulması gerektiği tartışılmış ancak GORBAÇOV dönemine kadar bu sağlanamamıştır. ${ }^{[57]}$

\section{1) Yapısı}

1936 Anayasası'nın 46. Maddesi ve 1977 Anayasasínın 119. Maddesine göre Yüksek Sovyet'in her iki kanadının katıldığı birleşik oturum ile Yüksek Sovyet Presidyumu oluşturulur. Yüksek Sovyet Presidyumu; başkan, başkan yardımcıları, sekreter ve üyelerden oluşmaktadır. ${ }^{[58]}$

1936 Anayasası́nın 48. Maddesine göre Yüksek Sovyet Presidyumu 37 üyeden oluşmaktadır. Bu üyeler Yüksek Sovyet'in her iki kamarasının da hazır bulunduğu ortak oturumda seçilmektedir. Yüksek Sovyet Presidyumu'nun; Başkanı, 11 adet başkan yardımcısı, Sekreteri ve 24 üyesi doğrudan ve sadece Yüksek Sovyet'e karşı sorumludur. 1977 Anayasası'nın 120. Maddesine göre ise Yüksek Sovyet Presidyumu; Başkan, Başkan Baş Yardımcısı, her bir birlik Cumhuriyetini temsil edecek toplam 15 Başkan Yardımcısı, bir Sekreter ve 21 üyeden oluşmaktadır.

1936 Anayasası döneminde Yüksek Sovyet Presidyumu'nun anayasal statüsünün belirsiz kaldığı ifade edilmektedir. Sovyet hukukçularının bir kısmı; Yüksek Sovyet Presidyumu'nun, Yüksek Sovyet'ten ayrı bir anayasal kurum olduğunu savunur iken diğerleri, daha önceki Birlik Merkezi Yürütme Kurulu ${ }^{[59]}$ gibi Yüksek Sovyet'in icrai komitesi olduğu yönünde görüş beyan etmişlerdir. Anayasal anlamda biçimsel ve fonksiyonel ola-

[56] UNGER, S. 211, KUTAFIN, S. 289.

[57] MAZO, S. 123-179, ÖZYURT, (Başkanın Konumu ve Fonksiyonu, 2021), S. $5-27$.

[58] GRIPP, S. 214.

[59] ÖZYURT, (Rus Tipi, 2021), S. 476-480. 
rak baktığımızda Yüksek Sovyet Presidyumu'nun münhasır bir anayasal kurum olarak değerlendirilme ihtimali çok azdır. Zira tamamen Yüksek Sovyet' in uhdesindeki yetkileri, o faaliyette değilken kullanmak üzere kurgulanmıştır. Ancak uygulamada Yüksek Sovyet' in sistem içerisinde işlevsel bakımdan varlığını görmek çok zor olduğu için Yüksek Sovyet Presidyumu münhasıran varlık gösteren bir kurum gibi gözükmektedir. ${ }^{[60]}$ Kanaatimizce her halükârda Yüksek Sovyet Presidyumu, Yüksek Sovyet'ten ayrı düşünülemez. Burada tartışılması gereken husus Yüksek Sovyet'in varlık amacını gerçekleştirememiş olması neticesinde fonksiyonel bakımdan Yüksek Sovyet' in yerini fiili olarak/ de facto almış olmasıdır.

\section{2) Yetkileri}

1936 Anayasası'nda, Yüksek Sovyet Presidyumu'nun yetki sınırları müphem bırakılmış daha sonra 1977 Anayasası ile bunlar büyük ölçüde somutlaştırılmıştır. ${ }^{[61]}$

Yüksek Sovyet Presidyumu'nun yetkilerinin sayıldığ 149 . Maddeye baktığımız takdirde, liberal temsili demokrasilerde parlamentonun yetkileri olarak ifade edilebilecek yetkilerin neredeyse tamamının burada yer aldığını görüyoruz. Dahası Yüksek Sovyet Presidyumu'nu Yüksek Sovyet' in başkanlık makamı olarak kurguladıklarını da görebiliyoruz. ${ }^{[62]}$ Tek bir kişinin başkan olması usul ve esasını Sovyet ideoloji ve fikri temeline aykırı olarak gören Sovyet anayasacıları, kolektif başkanlığa dair geleneksel tutumlarını burada da göstermişlerdir.

Yüksek Sovyet Presidyumu, kolektif devlet başkanlığı prensibi ile hareket etmektedir. Kararlar ve diğer işlemler Yüksek Sovyet Presidyum Başkanı ve Sekreteri tarafından birlikte imzalanarak yürürlüğe girebilmektedir. ${ }^{[63]}$

1936 Anayasanın 49. Maddesi Yüksek Sovyet Presidyumu'na kanun yapmak, kanun yayımlamak, af ilan etmek, referandum yapmak, ödül vermek, diplomatik temsilci atamak, Bakanlar Sovyeti'nin kararlarını iptal etmek, Genel Kurmay Başkanı'nı atamak ve azletmek, Yüksek Sovyeti feshedip yeni seçimleri ilan etmek, Bakanların atanmasını ve azledilmesini onaylamak, savaş ilan etmek, milletlerarası anlaşmaları onaylamak gibi bir-

\footnotetext{
[60] UNGER, S. 101.

[61] TOWSTER, S. 318.

[62] UNGER, S. 100, CHKHIKVADZADE, S. 124.

[63] CHKHIKVADZADE, S. 127.
} 
çok alanda çok geniş yetkiler vermiştir. Yüksek Sovyet Presidyumu; Yüksek Sovyeti toplantıya çağırabilir, kanunları yorumlayabilir, düzenleyici işlem olarak kararname çıkarabilir, referandum düzenleyebilir, af yayımlayabilir, seferberlik ilan edebilir. Bakanlar Sovyeti üyelerini, Yüksek Mahkeme üyelerini atayabilir ve azledebilir.

Yüksek Sovyet Presidyumu selefi olan Birlik Merkezi Yürütme Kurulu'nun elinde olan birtakım yetkilerden yoksun bırakılmışır. Yüksek Sovyet Presidyumu, Yüksek Sovyet'in bütün kararlarının icrai denetimini yapamamakta, Birlik Sovyeti'nin kararlarının uygulanmasını durduramamakta, Bakanlar Sovyeti'nin düzenleyici işlemlerini inceleme ve onaylama yetkisine sahip olamamaktadır. Yüksek Sovyet Presidyumu'nun, Yüksek Sovyet' in kararlarını veto yetkisi de yoktur.

1936 Anayasasi'nın 46. Maddesi ve 1977 Anayasası'nın 121. Maddesine göre Yüksek Sovyet Presidyumu'nun münhasıran kullanabileceği yetkiler; Yüksek Sovyet'in seçim tarihlerini belirlemek, Yüksek Sovyeti toplantıya çağırmak, Yüksek Sovyet' in iki kanadının çalışmalarının koordinasyonunu sağlamak, SSCB Anayasası'nın garantisi olmak, Birlik Cumhuriyetlerinin anayasalarının ve yasalarının SSCB Anayasası'na uyumlu olmasını temin etmek, SSCB kanunlarını yorumlamak, uluslararası anlaşmaları onaylamak ve/veya reddetmek, SSCB Bakanlar Sovyeti/Kurulu ve/ veya Birlik Cumhuriyetleri Bakanlar Sovyeti/Kurulu kararlarından kanuna aykırılık teşkil edenlerin yürürlügünü durdurmak, genel ve özel af ilan etmek, yabancı ülkelere veya uluslararası kuruluşlara diplomatik temsilci atamak ve/veya atananları geri çekmek, SSCB Genelkurmay Başkanı'nı atamak ve azletmek, Yüksek Sovyet' in toplantı dönemleri dışında ivedi durumlarda savaş ilan etmek, diğer anayasal kuruluşların SSCB Anayasası ve kanunlarına uygun çalışmasını temin etmek olarak sıralanmıştır. Ayrıca 1977 Anayasası'nın 123. Maddesi Yüksek Sovyet Presidyumu’na düzenleyici işlem olarak kararname yayınlayabilme yetkisi de vermektedir.

Yüksek Sovyet Presidyumu'nun belki de en can alıcı yetkisi, Yüksek Sovyet'in iki oturumu arasında -yani Yüksek Sovyet Genel Kurulu toplanmadığı zamanlarda- kararname ve yönetmelik yapabilmesidir. ${ }^{[6]]}$ Yüksek Sovyet Genel Kurulu'nun daimî toplanan bir organ olmaması göz önüne alındığında, Yüksek Sovyet Presidyumu'nun yasama yetkisini elinde bulunduran gerçek unsur olduğu anlaşılmaktadır. Her ne kadar Yüksek Sovyet

[64] GRIPP, S. 215, SCHAPIRO, S. 111. 
Presidyumu'nun kanun yapma yetkisi olmasa dahi kararnamelerin, muhtevası ve uygulanma gücü itibarıla, kanunlar gibi düzenlendiği bir gerçektir. ${ }^{[65]}$ 1938-1960 yılları arasında Yüksek Sovyet Genel Kurulu’nda 201 kanun yapılmıştır aynı tarih aralığında Yüksek Sovyet Genel Kurulu’nun oturum yapmadığı dönemlerde ise Yüksek Sovyet Presidyumu 105 kararname yapmıştır. ${ }^{[6]}$

Sovyet anayasa hukukçuları, Yüksek Sovyet Presidyumu'nun kararname çıkarma yetkisinin yeni bir kanun çıkarmaktan çok, var olan kanunların uygulanabilir hale getirilmesi için "kanunların somutlaştırılması" faaliyeti olduğunu ifade etmişlerdir. 1977 Anayasası'nın 122. Maddesinde Yüksek Sovyet Presidyumu'nun "yorumlama” ve "somutlaştırma” yetkisi düzenlenmiş, "SSCB'de uygulamada olan cari kanunları, ihtiyaç halinde, değiştirme" yetkisine sahip olduğu da sarih bir biçimde ifade olunmuştur. Ancak uygulamada Yüksek Sovyet Presidyumu'nun mezkûr faaliyetlerinin kanunları somutlaştırmaktan daha ciddi olduğu ortaya çıkmıştır. ${ }^{[6]} \mathrm{Ko}-$ nuya ilişkin olarak SSCB anayasa hukukçusu CHKHIKVADZADE'nin yorumu oldukça dikkati çekicidir. Yüksek Sovyet Presidyumu, kararname yolu ile anın vacibi uyarınca acil durumlarda "yeni bir hukuk veya düzen" oluşturabilmektedir. Böylesi kararnameler daha sonra Yüksek Sovyet tarafından onaylanmalıdır. ${ }^{[68]}$ Ancak bu "anın vacibi uyarınca acil durum" kavramı oldukça geniş ve esnek bir kavram olarak istisnai bir yolun genel prensip olarak algılanmasına peki ala yol açabilir. Zira SSCB'de de durum böyle olmuş, Yüksek Sovyet Presidyumu "olağan" durumlarda kanun yapan bir organa dönüşmüştür.

Temel olarak Yüksek Sovyet Presidyumu kanun yapmak değil kararname yapmak ile yetkilendirilmiş olsa dahi uygulamada Yüksek Sovyet Presidyumu, kanun yaratmıştır. Dahası uygulamada Yüksek Sovyet daimî faaliyet gösteren bir organ olmadığı için, Yüksek Sovyet Presidyumu'nun kararnameleri ile oluşturduğu "kanun düzeni" ile devlet idare edilmiştir. Daha sonra ise Yüksek Sovyet oturumlarında Yüksek Sovyet Presidyumu'nun kararnameleri bir kanun olarak kabul edilmiş, diğer bir deyiş ile onaylanmıştır. ${ }^{[69]}$

[65] TOWSTER, S. 320.

[66] GRIPP, S. 216.

[67] UNGER, S. 102.

[68] CHKHIKVADZADE, S. 127.

[69] SCHAPIRO, S. 111, TOWSTER, S. 320. 
Yüksek Sovyet Presidyumu'nun kararname yayımlama yetkisi açıkça Yüksek Sovyet'in kanun yapma yetkisinin yerini almıştır. Zira birçok Yüksek Sovyet Presidyumu kararnamesi, çok sonra Yüksek Sovyet tarafından onaylanarak kanunlaşmasına rağmen uzun süreler "hukuk düzeni" yaratmak imkânına sahip olmuştur. Yani bu kararnameler anayasada ifade edildiği üzere, kanunları uygulamak maksadı ile çıkarılmamıştır. Dahası Sovyet anayasacılarının ifade ettikleri üzere "acil durumlara müzahir kanun yapmak ihtiyacına binaen" de çıkarılmamıştır; bunlar doğrudan kanun karakterinde ve etkisinde çıkarılmıştır. Yüksek Sovyet'in bunlara ilişkin çok sonraları "onay" işlemi yapması da Yüksek Sovyet Presidyumu'nun "kararname çıkarma" tarz-1 usulünü de facto olarak tasdik ettiği yönünde peki ala yorumlanabilmektedir. ${ }^{[70]}$

Daha önce de ifade ettiğimiz üzere de jure olarak Yüksek Sovyet, esas kanun yapıcı olarak lanse edilse dahi uygulamada, de facto olarak Yüksek Sovyet Presidyumu ve Bakanlar Sovyeti esas kanun yapıcı olmuştur. Dolayısı ile kanunların somutlaştırılması olarak ifade edilmeye çalışılan, aslında anayasa gereği kanun yapmaması gereken Yüksek Sovyet Presidyumu'nun fiili sebepler gereği kanun yapma faaliyetinin yorum yolu ile meşrulaşt1rılmaya çalışılmasından başka bir şey değildir. Üstelik bunun bir sınırı da yoktur. Anayasa değişiklikleri için Yüksek Sovyet'in 2/3'lük karar yeter sayısı gerekmesine karşılık Yüksek Sovyet Presidyumu'nun kararnameleri ile anayasa değişikliği anlamı taşıyan düzenlemeler dahi yapılmış ve daha sonra bunlar Yüksek Sovyet tarafından resmi anayasa değişikliğine dönüştürülmüştür. ${ }^{[71]}$

1936 Anayasası'nın 146. Maddesi SSCB Anayasası'nda değişiklik yapma yetkisinin sadece Yüksek Sovyet'te olduğunu ve Yüksek Sovyet'in her iki kamarası tarafından ayrı ayrı yapılacak oylamalarda $2 / 3$ çoğunluk ile karar alınması durumunda anayasa değişikliği yapmanın mümkün olduğunu açıkça ifade etmiş ve herhangi bir istisna öngörmemiştir. Buna rağmen Yüksek Sovyet Presidyumu'nun anayasa değişikliği anlamına gelecek düzenleyici işlemler yaptığı ve bunların uygulandığı görülmektedir. 19 Mart 1966 tarihinde Yüksek Sovyet Presidyumu, Yüksek Sovyet'te Birlik Cumhuriyetlerinin temsilcisi sayısını 25'ten 32'ye çıkarma kararını almıştır. Esasen bu husus anayasada düzenlenmiş olduğu için anayasa değişikliği gerekmektedir. Yüksek Sovyet Presidyumu'nun kararı alıp uygulamasının

[70] TOWSTER, S. 323.

[71] SCHAPIRO, S. 111. 
ardından bu konu hakkında 3 Ağustos 1966 tarihinde Yüksek Sovyet anayasa değişikliği yapmıştır. Sovyet anayasa hukukçularının önemli bir kısmı tarafından; fiili olarak anayasanın bu şekilde delinmesi, sistemin tıkanmaması ve anayasal düzenin sağlıklı işleyişi için normal görülmüş ve "gerekli durumlarda", Yüksek Sovyet Presidyumu’nun anayasal sınırlarını aşabileceği yönünde mezkûr anayasaya aykırı durum savunulmuştur. ${ }^{[72]}$

Yüksek Sovyet Presidyumu'nun kanun yapma faaliyetine ilişkin açı bir hüküm yoktur. Ancak 1977 Anayasası'nın 123. Maddesinde yer alan "düzenleyici işlem ve kararname" yapma ve değiştirme yetkisi de hiç şüphe yok ki daha önceden bu yana süregelen "kanun yapma faaliyeti" için anayasal bir kaynak olarak kabul edilmiştir. Yüksek Sovyet Presidyumu’nun düzenleyici işlem yapması yetkisi Anayasa’nın 123. Maddesinde müstakil olarak ifade edilmiştir. Bu husus anayasa yapım tekniği açısından ilginç olmuştur. Zira 122. Maddede Yüksek Sovyet'in onayına muhtaç olan yetkiler tahdidi olarak sıralanırken, 121. Maddede de Yüksek Sovyet'in "onayına” ihtiyaç bulunmayan "müstakil" yetkiler belirtilmiş ve her iki maddede de Yüksek Sovyet Presidyumu'nun düzenleyici işlem yetkisinden hiç bahis olunmamıştır. Anayasa koyucunun doğrudan Yüksek Sovyet' in tekelinde olan kanun yapma yetkisini Yüksek Sovyet Presidyumu'na, "onaya" ihtiyaç bulunmadan "müstakil" kullanılacak yetki olarak özgülemediği açık olmakla birlikte "onaya" ilişkin de hüküm bulunmaması son derece tuhaf olmuştur.

Yüksek Sovyet Presidyumu'nun müstakil kullanacağı yetkilere ilişkin 1977 Anayasası'nın 121. Maddesi, aynı konuda düzenlemeler içeren 1936 Anayasası'nın 49.Maddesi ile büyük benzerlikler arz etmektedir. Bununla birlikte Yüksek Sovyet Presidyumu'na birkaç yeni yetki de tanınmıştır. Bunlardan ilki Yüksek Sovyet'in her iki kamarasının daimî komisyonlarını "koordine etme" yetkisidir. Diğeri ise 1924 Anayasası'ndakine benzer şekilde düzenlenen, "anayasal organların kendi yetkileri içerisinde faaliyet yürütmesini” denetleme yetkisidir.

1977 Anayasası'nın 122. Maddesi ise Yüksek Sovyet Presidyumu'na, Yüksek Sovyete vekâlet amacı taşıyan birtakım bağlı yetkiler de vermektedir. Bahse konu yetkilerin kullanılması münhasıran Yüksek Sovyet Presidyumu'na tanınmamıştır. Bu yetkilerin kullanılması durumunda, yetkinin kullanıldığı tarihten sonraya tekabül eden ilk Yüksek Sovyet Genel Kurul oturum döneminde, yapılan işlemin onaylanması için Yüksek Sovyet Genel Kurulu'na sunulması gerekmektedir. Bunlar Yüksek Sovyet'in

[72] MİSKETVIÇ, S. 102. 
oturum dönemleri haricinde ihtiyaç olması halinde kanunlarda değişiklik yapmak, Birlik Cumhuriyetlerinin sınır değişikliklerini onaylamak, Bakanlar Kurulu'nun tavsiyesi üzerine Bakanlıkları feshetmek yetkileri olarak ifade edilebilmektedir.

Yüksek Sovyet Presidyumu'nun bahse konu yetkileri dikkatlice tetkik edildiğinde görülecektir ki Presidyum hem yasama hem de yürütme kuvvetlerine münhasır yetkileri elinde bulunduran anayasal bir organdır. Kuvvetler ayrılığı prensibinin kabul görmediği SSCB'de, liberal temsili demokrasilerden farklı böylesi bir kurumun oluşması çok da yadırganmamalıdır.

\section{D) SSCB BAKANLAR SOVYETI/KURULU}

\section{1) Bakanlıkların Selefi Olarak Halkın Komiserleri Sovyeti}

SSCB'de bakanlar kurulu olarak görev yapan ve fakat ismi farklı olan Halk Komiserleri Sovyeti bulunmakta idi. Bu kapsamda 1924 Anayasası'na göre üç tip Halk Komiserliğinin bulunmakta olduğunu görüyoruz: Birlik, Birleşik ve Cumhuriyet Halk Komiserleri. Birlik Halk Komiserleri, beş tane olup bunlar harp işleri, diş ticaret, komünikasyon, posta ve telgraf işleri ile ilgilenmektedir. Bunlar SSCB çapında faaliyet yürüttükleri için Birlik Halk Komiserleri veya Bütün Birlik Halk Komiserleri olarak anılmaktadır. Bunların SSCB'yi oluşturan cumhuriyetlerde ve diğer federe unsurlarda örgütlenmiş biçimleri bulunmamaktadır. ${ }^{[73]}$

Bütün Birlik Halk Komiserleri'nin federe unsurlarda yetkili temsilcileri bulunmakta olup bahse konu faaliyetleri federal yapı adına yürütmektedirler. Bilahare İş ve Savunma Sovyeti bulunmakta olup bu konseye Halkın Komiserleri Sovyeti Başkanı başkanlık etmektedir. ${ }^{[7]}$

Birleşik Halk Komiserleri hem federe hem de federal anlamda örgütlenmektedirler. Yani bu komiserlikler federal anlamda SSCB'de ve federe anlamda diğer cumhuriyetlerde de bulunmaktadır. Milli Varlık Yüksek Sovyeti, Yiyecek, İş, Maliye ve İşşi-Çiftçi Teftiş olmak üzere beş Birleşik Halk Komiserliği bulunmaktadır. ${ }^{[75]}$

Cumhuriyet Halk Komiserleri ise yalnızca federe düzeyde örgütlenmektedirler. Bunlar Sosyal Güvenlik, Adalet, Sağlık, Eğitim ve benze-

[73] POPOV/MIGGRAÇEV/TİHOMİROV, (2011), S. 304.

[74] POPOV/MIGRAÇEV/TIHHOMİROV, (2011), S. 304.

[75] POPOV/MIGGAÇEV/TİHOMİROV, (2011), S. 305. 
ri alanlarda kurulabilmektedir. İkinci Cihan Harbinden sonra 15 Mart 1946 'da SSCB Halk Komiserleri Sovyeti reforma uğramış ve SSCB Bakanlar Sovyeti oluşmuştur. Halk Komiserlikleri Bakanlık olarak isimlendirilerek yeniden organize edilmiştir. ${ }^{[7]}$

\section{2) Bakanlar Sovyeti/Kurulu}

1936 Anayasası dönemine geldiğimizde Halkın Komiserleri Sovyeti yerine karşımıza Yüksek Sovyete bağlı olarak faaliyet yürüten Bakanlar Sovyeti çıkmaktadır. Bakanlar Sovyeti 1936 Anayasası'nın 79. Maddesi uyarınca benzer bir görevi ifa etmek için kurulan "Halk Komiserleri Konseyi'nin" halefi olup, 19 Mart 1946'dan sonra "Bakanlar Kurulu" adını almıştır. Bakanlar Kurulu 1977 tarihli SSCB Anayasası'nın 128. Maddesine göre SSCB' nin hükümeti ve en yüksek yürütme ve idari organıdır. Esas olarak Yüksek Sovyete karşı sorumlu ancak Yüksek Sovyet oturumları arasında Yüksek Sovyet Presidyumu'na karşı sorumlu olarak faaliyetlerini yürütmektedir. Bakanlar Sovyeti/Kurulu yapısının önemli bir kısmı Sovyetler Birliği Komünist Partisi ileri gelen üyelerinden oluşmaktadır. ${ }^{[77]}$

Bütün Birlik Bakanları ve Birlik Cumhuriyeti Bakanları olmak üzere iki tip bakanlık vardır. Bütün Birlik Bakanları, tüm SSCB’yi ilgilendiren konular ile ilgilenir iken federe unsurlarda her zaman karşılıkları yoktur ve gereken durumlarda karşılıkları ihdas edilebilir. Bütün Cumhuriyet Bakanları ise federe düzeyde görülen işlerin Birlik düzeyinde yürütülmesinden sorumludur. Her federe unsur içerisinde karşıllkları olarak bir federe bakanları bulunmaktadır. ${ }^{[78]}$

1936 Anayasası'nın ilk haline göre Bakanlar Sovyeti'nin yapısı ve genişliği işlevsel olmaktan uzaktır. Bundan dolayı devam eden süreçte kademeli olarak Bakanlar Sovyeti'nin yapısına ilişkin değişiklikler yapılmış ve daha işlevsel bir anayasal organ oluşturulmaya çalışılmıştır. 1936'da 24 üyeden oluşan Bakanlar Sovyeti, 1976 yılına gelindiğinde 105 üyeden müteşekkil hale gelmiştir. Bu genişleme SSCB'nin kompleks ve alabildiğine karmaşık yapısının idaresi anlamında bir zaruret olarak ifade edilmiştir. Mesela 1956 yılında Adalet Bakanlığı, 1960 yılında İç İşleri Bakanlığı, SSCB’nin Bakanlar Sovyeti'nden kaldırlarak bunların yetkileri federe unsurlarda kurulacak federe bakanlıklara devredilmiştir. Fakat 1966 yılında İçişleri

[76] POPOV/MIGRAÇEV/TIHHOMİROV, (2011), S. 305.

[77] SCHAPIRO, S.118, KIRICHENKO/DENISOV, S. 317, TOWSTER, S. 324.

[78] SCHAPIRO, S. 117, STEŞANKO/ŞAMBA, S. 271-273. 
Bakanlığı, 1970 yılında ise Adalet Bakanlığı, Bakanlar Sovyeti bünyesinde tekrar kurulmuştur. ${ }^{[79]}$

Bakanlar Sovyeti Presidyumu fiili olarak 1953'ten beri var olmasina karşın anayasal bir karşılığı bulunmamakta idi. 1977 Anayasası’nın 132. Maddesi Bakanlar Sovyeti Presidyumu'nu, Bakanlar Sovyeti'nin "daimî organı" olarak tanımlayarak bu organa anayasal bir statü kazandırmıştır. Aynı maddeye göre Bakanlar Sovyeti Presidyumu; başkan, birinci başkan yardımcısı ve başkan yardımcılarından müteşekkildir. 19 Nisan 1979'da göreve başlayan 109 üyeli Bakanlar Sovyeti Presidyumu; başkan, birinci başkan yardımcısı ve 12 adet başkan yardımcısından oluşmakta idi. Esasen Bakanlar Sovyeti Presidyumu, bir iç kabine olarak kabul edilmektedir. ${ }^{[80]}$

Bakanlar Sovyeti, siyasi bir organ olmaktan ziyade konusunda uzman kişilerin bakan olarak tayin edildiği teknokratik bir yapıdır. Sayının giderek artması ile birlikte burası liberal temsili demokrasilerdeki kabine veya bakanlar kurulunun işlev ve yapısından uzaklaşmıştır. Siyaseti belirlemekten ziyade uygulamak anlamında bir etki göstermiştir. Fakat bu noktada aşırı genişlemesi neticesinde zamanla etkisiz veya etkisi kısırlaşan bir kuruma dönüşmüştür. ${ }^{[81]}$ Muhtelif idari organların koordinasyonu ile ilgilenmek üzere daha dar kapsamlı olan Bakanlar Sovyeti Presidyumu oluşturulmuştur. İlginçtir ki, böyle bir kurumun varlığı ancak STALİN'in ölümünden sonra kamuoyu tarafından öğrenilmiştir. ${ }^{[82]}$

Hükümet olarak ifade edilebilecek olan Bakanlar Sovyeti, en yüksek yürütme organı ve idari makamdır. Bakanlar Sovyeti, merkezi hükümetin iştigal alanları ile doğrudan sorumludur. Milli ekonomik plan ve bütçeyi denetler, dış ilişkileri tesis eder, silahlı kuvvetleri yönetir. ${ }^{[83]}$

Bakanlar Sovyeti'nin başında bir başkan bulunmaktadır. Esasen bu liberal temsili demokrasilerdeki başbakana tekabül etmektedir. ${ }^{[84]}$ Ancak Sovyet ideolojisinin liberal temsili demokrasilere ilişkin kavramları kullanmamaya ilişkin tavrı dolayısı ile "başbakan” ifadesi kullanılmamaktadır. STALIN, Bakanlar Sovyeti Başkanlığı ile partinin üst düzey yönetimini

[79] UNGER, S. 107, SCHAPIRO, S. 116.

[80] SCHAPIRO, S. 117.

[81] UNGER, S. 108, KIRICHENKO/DENISOV, S. 317.

[82] UNGER, S. 109, STEŞANKO/ŞAMBA, S. 267-269.

[83] GRIPP, S. 203, UNGER, S. 105.

[84] GRIPP, S. 209, KIRICHENKO/DENISOV, S. 315. 
eşleyerek, partinin konumunu güçlendirmiştir. STALİN'in ölümünün ardından Sovyetler Birliği Komünist Partisi Genel Sekreteri olan KRUŞEV, aynı zamanda Bakanlar Sovyeti Başkanı olarak da görev yapmıştır. ${ }^{[85]}$

Bakanlar Sovyeti'nin, Yüksek Sovyet' in birleşik oturumu ile seçilmesi usulü Anayasa'da açıkça kabul edilmiştir. Ancak Yüksek Sovyet kendiliğinden bu seçimi yapmamaktadır. Bakanlar Sovyeti Presidyumu'nun tayin ettiği Bakanlar Sovyeti Başkanı'nın hazırladığı bakan listelerinin, Yüksek Sovyet tarafından onaylanması ile Bakanlar Sovyeti teşekkül etmektedir. Diğer bir deyişle Bakanlar Sovyeti Başkanı, Yüksek Sovyet'in onayı ile bakanları atama yetkisine sahiptir. ${ }^{[86]}$ Bakanlar Sovyeti'nin yetkileri, görüldüğü üzere oldukça fazladır.

Bakanlar Sovyeti, Yüksek Sovyet tarafından oluşturulmakta ve ona karşı sorumlu olarak faaliyet yürüterek hesap vermektedir. Bakanlar Sovyeti esas olarak Yüksek Sovyet'in oturum dönemleri arasında, onun nam ve hesabına faaliyet yürütmektedir. Yüksek Sovyet' in oturum yapmadığı dönemlerde -yani dönem aralarında- Yüksek Sovyet Presidyumu; bakanları, Bakanlar Sovyeti Başkanı'nın teklifi ile azledebilir ve aynı usul ile atama yapabilir. ${ }^{[87]}$

Bakanlar Sovyeti'ni oluşturan bakanların her birisi de şahsi olarak, Yüksek Sovyet'e karşı sorumlu olarak hareket etmektedir. 1977 Anayasası'na göre kabine, faaliyetleri ile ilgili olarak Yüksek Sovyeti, düzenli olarak bilgilendirmek zorundadır. Yüksek Sovyet'in sürekli oturum düzenleyen bir parlamento olmamasından dolayı, Yüksek Sovyet'in toplanmadığı zamanlarda Bakanlar Sovyeti/Kurulu, Yüksek Sovyet Presidyumu'na karşı sorumludur. Daha önce ifade edildiği gibi hem Yüksek Sovyet'in hem de Yüksek Sovyet Presidyumu'nun bakanları azletme yetkisi mevcuttur.

Diğer anayasal organlarda olduğu gibi Bakanlar Sovyeti açısından da SSCB'nin, liberal temsili demokrasilerde yer alan Bakanlar Kurulu'ndan birtakım önemli farklılıkları bulunmaktadır. Öncelikle SSCB tek partili siyasi bir düzendir. Bu düzen içerisinde, liberal temsili demokrasilerde algılanan biçimiyle bir muhalefetten bahsetmek mümkün değildir. Dolayısı ile hükümetin faaliyetlerini siyasi olarak denetleyecek bir muhalefetten çe-

[85] SCHAPIRO, S. 117, KIRICHENKO/DENISOV, S. 317, ÇİRKİN, (2013), S. 17.

[86] GRIPP, S. 209, UNGER, S. 105.

[87] TOWSTER, S. 325. 
kinilmesine gerek yoktur. Bir diğer önemli farklılık ise bakanlar kurulunun herhangi bir anayasal yetkiye dayanarak meclisi feshetme, seçimleri yenileme ve buna benzer bir yetki ile donatılmamasıdır. Bu kapsamda bakanlar kurulunun, SSCB'de bürokrasinin yani idarenin başı sıfatıyla hareket eden bir yürütme organ olduğu ifade edilebilecektir. ${ }^{[88]}$

Bahse konu farklılıklar dışında bakanlar kurulu, icrai anlamda liberal temsili demokrasilerdekine benzer bir işlev görmektedir. SSCB Bakanlar Sovyeti/Kurulu, Yüksek Sovyet ve Yüksek Sovyet Presidyumu'ndan aldığ salahiyet ile SSCB Anayasası'na bağlı olarak yürütme organının tüm idari işlerini yapmak görevini üstlenmiştir. Yüksek Sovyet ve Yüksek Sovyet Presidyumu’nun tesis ettiği politikaların yürütülmesinden Bakanlar Kurulu mesuldür. Bu kapsamda ekonomik, sosyal ve kültürel alanda ilerlemeyi temin etmek, toplumsal refahı tesis etmek, bilimsel gelişmeyi sağlamak, doğal kaynakların keşfi ve verimli kullanılmasını temin etmek, sosyal güvenlik politikalarını düzenlemek; endüstri, inşaat, tarım, nakliye, komünikasyon alanlarındaki kurumların yönetimi; cari ve uzun vadeli ekonomik ve sosyal devlet planlarını yürütmek, bütçeyi Yüksek Sovyet'e sunmak, devlet bütçesini uygulamak, devlet bütçesinin kullanılması ile ilgili olarak Yüksek Sovyet'e rapor sunmak; devletin menfaatlerini, kamu düzenini, sosyalist mülkiyeti korumak ve vatandaşların hak ve hürriyetlerini garanti altına almak; devlet güvenliğini sağlamak üzere tedbirler almak; diğer devletlerle ekonomik, bilimsel, teknik ve kültürel konularda ilişki kurmak ve yönetmek, uluslararası antlaşmaların kabulünün ardından uygulanması için gerekli önlemlerin alınması, hususlarında Bakanlar Sovyeti/Kurulu yetkilidir. Ayrıca anayasanın 135. Maddesine göre düzenleyici işlem de yapabilmektedir.

Bakanlar Sovyeti'nin, icrai bir organı olarak Presidyumu bulunmaktadır. Bakanlar Sovyeti Presidyumu; başkan, 2 tane birinci başkan yardımcısı, muhtelif sayıda başkan yardımcısından oluşmaktadır. Bakanlar Sovyeti Presidyumu, ad hoc komisyonlar ve özel çalışma grupları kurabilmektedir. Bakanlar Sovyeti Presidyumu, Bakanlar Sovyeti'nde görüşülmesi ve çözümlenmesi gereken meseleleri belirleyerek bunları düzene koymaktadir. ${ }^{[89]}$ Esasen Bakanlar Sovyeti Presidyumu, Bakanlar Sovyeti'nin içerisinde daha dar kapsamlı bir kabineden başka bir şey değildir. ${ }^{[90]}$

\footnotetext{
[88] ŞEN, S. 49, KIRICHENKO/DENISOV, S. 317.

[89] GRIPP, S. 209.

[90] GRIPP, S. 210.
} 
Daha önce ifade edildiği gibi Bakanlar Sovyeti/Kurulu, çeşitli bakanlıkların yanı sıra muhtelif konularda kurulan komisyonları da ihtiva etmektedir. 1977 Anayasası'nın 132. Maddesine göre Bakanlar Sovyeti/Kurulu Başkanlı $\breve{g}^{[91]}$; başkan, başkanın birinci yardımcısı, başkan yardımcıları ve bakanlardan oluşmaktadır.

Bakanlar Sovyeti/Kurulu'nun yetkileri, 1936 Anayasası' na göre 1977 Anayasası'nda daha özenle hüküm altına alınmış, kurul hakkında daha az müphem nokta bırakılmıştır. Bu kapsamdaki en önemli değişiklik, 1936 Anayasası'nda Bakanlar Sovyeti'nin yürürlükteki kanunlara göre düzenleyici işlem yapma yetkisine karşılık, 1977 Anayasası'nın yürürlükteki kanunlar ve Yüksek Sovyet ile Yüksek Sovyet Presidyumu'nun kararlarına göre düzenleyici işlem yapma yetkisi veren 133. Maddesi'dir.

1977 Anayasası'nın 134. Maddesi SSCB Bakanlar Kurulu'na, federe unsurların yürütme organları üzerinde kullanılmak üzere denetim yetkisi vermiştir. Buna göre SSCB Bakanlar Kurulu, federe hükümetlerin çıkarmış olduğu düzenleyici işlemlerin yürürlüğünü durdurabilmektedir. Ayrıca 135. Madde hükümlerine göre Bakanlar Kurulu, federe unsuların hükümetleri ile koordinasyonu sağlamak yetki ve görevine de sahiptir.

SSCB'nin esas yasama organı Yüksek Sovyet olmakla birlikte oluşan kanunların önemli bir kısmı Bakanlar Sovyeti/Kurulu kaynaklıdır. Diğer yandan Bakanlar Sovyeti/Kurulu'nun kanun tasarısı sunma yetkisi de mevcuttur. Bakanlar Sovyeti/Kurulu, SSCB'nin münhasıran yürütme organı olmasina ve teorik olarak yasama fonksiyonuna sahip olmamasina karşın, Yüksek Sovyet tarafından henüz kabul edilmemiş bir taslağı kanun olarak yürürlüğe koyma yetki ve gücüne de sahiptir. ${ }^{[22]}$ Bakanlar Sovyeti/ Kurulu'nun kanun tasarıları Yüksek Sovyet tarafından çok nadir reddedilmiştir. ${ }^{[93]}$

Bakanlar Sovyeti/Kurulu'nun düzenleyici işlemlerinin sınırlarına ilişkin Anayasảda veya diğer düzenlemelerde açık sınırlamalara rastlayamıyoruz. Dahası bu düzenleyici işlemlerin çok önemli bir kısmı da kamu-

[91] Anayasa, Bakanlar Konseyi Presidyumu olarak ifade etmiştir. Ancak Türkçeye aktarırken Bakanlar Kurulu Başkanlığı şeklinde tercüme etmeyi terim birliği açısından daha faydalı bulmaktayız. Ancak metin içerisinde aslına uygun kullanımda da bulunulmuştur.

[92] GRIPP, S. 211.

[93] GRIPP, S. 216, KIRICHENKO/DENISOV, S. 317 
ya duyurulmamış yani yayımlanmamıştır. 2 Ekim 1940 tarihli Bakanlar Sovyeti'nin düzenleyici işlem niteliğindeki kararnamesi ile Anayasảnın 121. Maddesinde yer alan ücretsiz ve temel eğitime dair hükümler değiştirilmiş, Yüksek Sovyet ise bunu tam altı yıl sonra 25 Şubat 1947'de resmi bir anayasa değişikliğine dönüştürmüştür. ${ }^{[9]}$

Bakanlar Sovyeti/Kurulu'nun kararname ve emir yayımlama yetkisinin, Yüksek Sovyet'in yasama yetkisini ne derece gasp ettiği şüphelidir. Uygulamada görülmektedir ki, Bakanlar Sovyeti/Konseyi'nin düzenleyici işlemleri, zaman zaman yasamanın "kanunları" ile aynı özellikleri taşımaktadır. Bakanlar Sovyeti/Kurulu’nun düzenleyici işlemleri ile Yüksek Sovyet Presidyumu'nun kararnameleri arasındaki en temel fark ise; Bakanlar Sovyeti/Kurulu düzenleyici işlemlerinin, Yüksek Sovyet Presidyumu tarafından yürütmesinin durdurulabiliyor ve iptal ediliyor olmasıdır. Diğer yandan Yüksek Sovyet Presidyumu'nun kararnameleri ise Yüksek Sovyet tarafından "kanunlaşmaz" ise yürürlükten kalkmaktadır. Yani Yüksek Sovyet Presidyumu' nun kararnamelerini iptal edecek bir makam yoktur, bunlara ilişkin ancak kanunlaşma veya kanunlaşmama kararı alınabilmektedir. Bu noktada Yüksek Sovyet Presidyumu'nun daimî faal bir organ olmasına karşın Yüksek Sovyet' in daimî faal olmayan bir organ olması da "işlemlerin” yürürlüğüne ve denetim yapan organın etkinliğine ilişkin çok önemli bir veri sunmaktadır. ${ }^{[95]}$

\section{E) ANAYASAL BİR KURUM OLARAK SOVYETLER BİRLiĞi KOMÜNIST PARTISI (SBKP)}

SSCB yapısı içerisinde düzenlenen her kurumsal yapı üzerinde mutlak etkisi bulunan tek yapı fiili olarak SBKP'dir. Devlete egemen olan tek parti yapısı, diğer deyişle totaliter yapının gereği olarak SBKP, devlet iktidarının kullanım vasıtalarına erişimin tek yoludur. Teori ve pratiğe göre tüm yasama faaliyetinin ve diğer anayasal organların faaliyetlerinin kaynağı SBKP'dir. ${ }^{[96]}$ SBKP, devlet iktidarının çekirdeğini oluşturmaktadır. Tüm devlet organları SBKP'nin politikalarını realize etmek için faaliyet yürütmektedir. ${ }^{[97]}$ Resmi Sovyet ideoloji ve hukuk tezlerinde devlet başkanlığı fonksiyonunu Yüksek Sovyet Presidyumu’nun yerine getirdiği

\footnotetext{
[94] UNGER, S. 102.

[95] TOWSTER, S. 325.

[96] SCHAPIRO, S. 86, ASKER, S. 191.

[97] BRAHAM, S. 307.
} 
ifade edilmesine karşın bu işlevi SBKP Genel Sekreterliği yerine getirmektedir. SBKP Genel Sekreteri'nin aynı zamanda Yüksek Sovyet Presidyumu Başkanı olarak görev yapmaya başlaması ile de facto olan bu durum de jure hale getirilmiştir. ${ }^{[98]}$ ÇIRKİN'in ifade ettiği üzere STALİN, SSCB döneminde hiçbir devlet organının doğrudan başında olmamasına rağmen SBKP Partisi Genel Sekreteri sıfatı ile devletin başı olarak görülmektedir. İşte bu fiili durum zamanla anayasal bir hale getirilmiştir. ${ }^{[99]}$

Parti üyesi olmak son derece zordur. 18 yaşını doldurmuş SSCB vatandaşları partiye başvuru yapabilmektedir. Ancak doğrudan üye olamamaktadır. 18-23 yaş arası SSCB vatandaşları öncelikle Parti'nin gençlik organizasyonu olan Komsomol'a ${ }^{[100]}$ üye olmak durumundadır.

Partiye başvuru yapan şahsın, en az 5 yıl kıdemi bulunan 3 kişi tarafından partiye olumlu referansı gerekmektedir. Üstelik referans olacak şahıslar, parti üyeliğine aday olan şahsa ilişkin alelade bir referans sunamamaktadır. Referanslar, adayı toplumsal organizasyonlar ve/veya iş sebebiyle en az bir sene tanıyor olmak gibi bir keyfiyeti de açılamak ile mükelleftir. ${ }^{[101]}$

Görüldüğü üzere SBKP’ye üye olmak için birden çok denetim mekanizmasından geçmek gerekmektedir. Bu durumun bilinçli bir şekilde oluşturulduğu aşikardır. SBKP üye sayısının SSCB nüfusuna oranla oldukça düşük tutularak, seçkin bir komünist elit yaratılması amaçlanmıştır. ${ }^{[102]}$

LENIN'in ifade ettiği üzere, askeri nizam ve disiplin içerisinde, geniş yetkilerle donatılmış olan bir parti, sistem için faydalı olabilecektir. ${ }^{[103]}$ Bahse konu disiplin ve nizamı sağlayacak olan ise "demokratik merkeziyetçilik" ilkesidir.

Demokratik merkeziyetçilik ilkesine göre, parti merkezi tarafından alınana kararların tüm kadrolar tarafından uygulanması ve önemli kararların ancak parti merkezi tarafından alınması söz konusudur. Parti merkezinin aldığı kararlar, sınırlı olarak dahi olsa sorgulanamamakta ve bu kararla-

[98] KUTAFIN, S. 289, AVAKYAN, S. 39-52, İSAEV/BARANOV, S. 286-290.

[99] ÇİRKİN, (2015), S. 17.

[100] Türkçeye Leninist Komünist Gençler Birliği şeklinde tercüme edebileceğimiz ifadenin Rusça kısaltmasıdır.

[101] AVAKYAN, S. 39-52.

[102] REMINGTON, S. 31, İSAEV/BARANOV, S. 290-296

[103] TÜRKKAYA, S. 62 
rın aleyhinde faaliyetlerde bulunmak mutlak biçimde yasaklanmaktadır. Hiyerarşik olarak üstte yer alan organların kararları, alttakiler açısından mutlak suretle bağlayıcıdır. ${ }^{[104]}$

Liberal temsili demokrasilerde parti içi muhalefet olarak adlandırılan husus, SSCB'de katiyen yer bulamamaktadır. Ancak buna mukabil "öz eleştiri” adı verilen bir ilke mevcuttur. Alınan kararın yerindeliği ve doğru olup olmadığı yönünde eleştiri yapma hakkı, ancak hiyerarşik olarak üstte olan makamın alttakine karşı kullanabileceği şekilde mevcuttur. Diğer durumda alt makamdakinin üstüne karşı böylesi bir tutuma girmesi, demokratik merkeziyetçilik ilkesi ile çelişeceği için söz konusu dahi olamamaktadır. Alt makamda yer alanların, hiyerarşik üstlerine ilişkin yapabilecekleri eleştiri alınan kararın yerindeliğinden ziyade uygulanmasında ortaya çıkan durumlarla ilgili olabilmektedir.

Bahse konu ilkeler her ne kadar Komünist Parti'nin ilkeleri olarak karşımıza çıksa dahi, devlet iktidarına ulaşmanın tek meşru yolu olan partinin kabul ettiği düsturlar, devletin genel kabul gören ilkeleri haline gelmekte, dahası toplum için de dahi uyulması gereken kurallar olarak algılanmaktadır. ${ }^{[105]}$

Parti'nin karar alma ve yönetim organı Parti Kongresi'dir. Kongre olağan olarak 5 yılda bir toplanmaktadır. Uzun aralıklar ile toplanan Parti Kongresi'nin iki toplanması arasında parti faaliyetlerini yürütmek üzere, Merkez Komitesi adı verilen bir parti organı yetkilendirilmiştir. Politbüro adı verilen bir diğer parti organı bulunmaktadır. Politbüro; SBKP Genel Sekreteri, Bakanlar Kurulu Başkanı, Savunma Bakanı, İstihbarat Servisi (KGB) Başkanı, Dışişleri Bakanı ve bazı federe unsur yöneticilerinden meydana gelmek bakımından son derece etkili bir parti organıdır. ${ }^{[106]}$

Devletin en yüksek iktidarı, Yüksek Sovyet ve ona karşı sorumlu olan diğer organlar olarak ifade edilse dahi tüm devlet iktidarı SBKP tarafından dolaylı olarak yönetilmektedir. Yüksek Sovyet'in dönem arasında daimî olarak faaliyet gösteren en mühim ögesi olan Yüksek Sovyet Presidyumu üyelerinin önemli bir kısmının SBKP'de de görevli olması partinin, Yüksek Sovyet Presidyumu üzerindeki etkisini de yoruma hacet birakmayacak şekilde açıklamaktadır. ${ }^{[107]}$

[104] AVAKYAN, S. 39-52, İSAEV/BARANOV, S. 286-290.

[105] TÜRKKAYA, S. 162, AVAKYAN, S. 27.33.

[106] REMINGTON, S. 32, İSAEV/BARANOV, S. 286-290.

[107] BRAHAM, S. 307, AVAKYAN, S. 27.33, İSAEV/BARANOV, S. 286-290. 


\section{F) SONUÇ VE DEĞERLENDIRME}

1917 Sovyet Devrimi ile oluşan atmosfer içerisinde dünyanın geri kalanından farklı bir hükümet sistemi üretme çabasının ürünü olan kuvvetler birliği ve/veya karma hükümet sistemli kolektif başkanlık modeli, 1970’lerin sonlarına gelindiğinde artık fonksiyonel olarak görülmemeye başlanmıştır. Buna ilişkin anayasal düzenlemeler ihdas edilmiş ve 1993 Anayasası olarak ifade edilen mevcut anayasal düzen ortaya çıkmıştır. Özellikle Yüksek Sovyet' in yapısı ve ona yüklenen vazifeler oldukça tezat oluşturmuştur. 1500 kişiye yakın üyesi bulunan böylesi bir yapının, üstelik yılda 8-10 gün mesai yaparak devletin yasama ve yürütmeye ilişkin her tür iş ve işlemini yapabilmesini beklemek doğru değildir. Sovyet ideologlarının en temel hatası buradadır. Geçen uzun yıllar ise bu hatalı tercihin sslah edilmesi için harcanan bir çaba olarak görülmelidir.

Yüksek Sovyet Presidyumu, başarılı denilebilecek bir yapıdır. Çıkardığı düzenleyici işlemler ile parlamentonun yasama fonksiyonunu gerçekleştirmiş, yürütmeye ilişkin ise görevlerini yerine getirebilmiştir. Bu bakımdan konu ele alındığında kuvvetler birliği ve kolektif başkanlık teorisinin vücut bulduğu yerin Yüksek Sovyet Presidyumu olduğu görülecektir. Ancak burada da Yüksek Sovyet Presidyumu Başkanı konusunda uzun yıllar tereddütlerin yaşanması sorun oluşturmuştur. Açıkça ifade etmek gerekir ki kolektif başkanlık tezi hemen hiç uygulanmamıştır. Sistemsel boşluklar SBKP Genel Sekreteri'nin bazen resmi bazen de gayri resmi görev tanımlamaları ile dolduruluştur. Zira yürütme fonksiyonu yasama fonksiyonu gibi değildir. Yürütücü iş ve işlemlere ilişkin sorumluluğun ortaklaşa üstlenilmesi ve bunun yürütülmesi oldukça güçtür. Bundan dolayıdır ki 1970’lere gelindiğinde bu kolektivite iddiasından da vazgeçilerek, başkanlık diyebileceğimiz bir yapıya gelinmiştir.

1990’lı yıllara geldiğimizde Yüksek Sovyet yapısı üzerindeki reformlar onun bir parlamento olarak reorganize edilmesine kadar gitmiştir. Yüksek Sovyet Presidyumu başkanlığa, Bakanlar Sovyeti ise başbakanlığa evirilmiştir. Ancak Yüksek Sovyet Presidyumu’nun kuvvetler birliği döneminde yürütmeden fazlası olması sebebi ile yeni dönem Rus tipi başkanlık modelinde, kuvvetler ayrılı̆̆ı benimsenmesine rağmen anayasada, başkan hiçbir kuvvet içerisinde zikredilmeyerek aslında Sovyet dönemine en uygun form hayata geçirilmiştir. 
Mevcut hali ile Rusya'da başkanlık, Sovyet dönemi kurumlarının kuvvetler ayrıllı̆̆ına göre rasyonalize edilmesi ile yeniden tesis edilmiştir. Diğer başkanlık modellerinden farklı olarak bir başbakanın bulunmasının esas sebebi Yüksek Sovyet Presidyumu ve Bakanlar Sovyeti'nin teamülen devam ettirilmesinden başka bir şey değildir. Başbakan ve bakanların yetki ve sorumlulukları neredeyse Bakanlar Sovyeti'ninki ile aynıdır. Üstelik Başbakanlığın dışarıdan bakılınca etkisiz ve anlamsız gelen varlığı dahi Sovyet konteksi içerisinde ele alınır ve Bakanlar Sovyeti ile mukayese edilir ise son derece anlamlidır.

Ruslar Sovyet ideologlarının taassubunda kurtulmuş ancak Sovyet geleneklerini terk etmemişlerdir. Parlamentonun mevcut yetkinliği ve etki oranı da bu kapsamda Yüksek Sovyet ile mukayese edilmelidir. Ruslar hemen hiçbir zaman gerçek anlamda bir parlamento özlemi içerisinde olmamıştır. Onlar sürekli olarak yürütme ve onun fonksiyonalitesi üzerine tartışmışlardır. Onlar için sürekli açık olan daimî bir kanun yapan yer olarak parlamentonun varlığı yeterlidir. Üstelik parlamentodan anlaşılan ise temsil ve kanun yapma meselesidir. Hükümetin denetlenmesi gibi konular çok yeni kavramlardır. Bu ise Yüksek Sovyet'in toplumun her kesimini temsil etme idealinin sürdürülmesidir.

Topyekûn bakıldığı zaman Yüksek Sovyet, Yüksek Sovyet Presidyumu, Bakanlar Sovyeti üzerindeki bütün ihtilaflı meseleler ve sorunlar, sosyalist terminoloji dışına çıkılarak çözülmüştür. Üstelik ortaya farklı kurum ve yapıları ile zengin bir anayasal düzen çıkmıştır. Buna ön yargılı ve/veya sadece klasik anayasal jargonlar ile bakılması durumunda birçok şey eksik veya aksak görülecektir. Ancak kendi iç dinamikleri içerisinde bakıldığında her şey yerli yerine oturmaktadır. Zira yeni anayasal düzen liberal temsili demokrasilerdeki hükümet modellerine göre dizayn edilmiş değildir. Böyle bir çaba olmamıştır. Yeni dönem anayasası SSCB anayasal düzeninde eksik, aksayan hususların ve konuların dizayn edilmesi ile oluşmuştur. Kolektif başkanlıktan başkanlığa geçilmiş, kuvvetler birliği Yüksek Sovyeti'nden kuvvetler ayrılığı Federal Meclisine geçilmiştir. Ancak kolejyal hükümet olarak Bakanlar Sovyeti'nin yapısı neredeyse aynen muhafaza edilmiştir. 
Kolektif Başkanlık Teorisine Göre Yüksek Sovyet: İcra Kurulu Olarak Yüksek Sovyet Presidyumu ve Hükümet Organı Olarak Bakanlar Sovyeti

\section{KAYNAKÇA}

ASKER,A.,(2015). Rusya'da Yönetim Geleneğinin Değişmeyen Özelliği: Güçü Yürütme. Başkanlık Sistemi. Ankara: Liberte Yayınları.

AVAKYAN,S.,(2011). Konstitutsionno-Pravovoy Status Politiçeskih Partiy V Rossi. İzadatelstvo Norma.

BRAHAM,R.,(1965). Soviet Politics and Government. New York: Alfred A Knopf Publisher.

ÇAM,E., (1982). Devlet Sistemleri. İstanbul: İstanbul Üniversitesi Yayınları.

CHKHIKVADZADE,V.,(1972). The Soviet Form Of Popular Government, Moscox: Progress Publishers.

ÇİRKIN,V.,(2013). Glava Gosudarstva: Sravnitelno-pravovoe İsledovanie. Moskova: İzdatelstvo Norma.

ÇİRKİN,V.,(2015). Zakonodatelnaya Vlast. Moskova: İzdatelstvo Norma.

GRIPP, R., (1967). Pattern Of Soviet Politics. Homewood/Illioms: The Dorsey Press.

GÜRBÜZ, Y., (1987). Karşzlaşttrmalı Siyasal Sistemler. İstanbul: Beta Yayınları.

HENDERSON,J.,(2011).The Constitution of The Russian Federation: A Contextual Analysis. Oxford: Hart Publishing.

HUSKEY,E.,(1992). "Executive-Legislative Relations", Executive Power and Soviet Politics: The Rise and Decline of the Soviet State. New York.

İSAEV,B.A.,BARANOV,N.A.,(2013). Sovremennaya Rossiyskaya Politika. Moskva: Piter.

KIRICHENKO, M./DENISOV, A.,(1965). "Soviet Constitutionalism". Soviet Politics and Government. New York : Alfred A Knopf Publisher.

KUTAFIN,O.E.,(2014). Glava Gosudarstva. Moskva: Prospekt.

LAZAREV,V.V.,(1991). Prezident SSSR. Moskva: İzdatestvo Nauka. 
MAZO, E.D., (2005). Constitutional Roulette: The Russian Parliament's Battles with the President over Appointing a Prime Minister. Standford Journal Of International Law, Vol. 41, No: 123.

MİSKETVİÇ, A.V.,(1967). Aktı Vış̧ih Organov Sovetskovo Gosudarctva. Moskva: Yuridiçeskaya Literatura.

MUHAMEDOVA,R.H.,(1980). Prezidium Verhovnovo Soveta Soyoznoy Respubliki, Taşkent: İzdatelstvo FAN.

ÖZYURT,D.,(2021). Rusya Federasyonu Anayasal Düzeninde Devlet Başkanının Konumu ve Fonksiyonu. Ankara: Adalet Yayınevi.

ÖZYURT,D.,(2021). Rus Tipi Başkanlık Modeline Giden Yolda 1918 Rusya ve 1924, 1936, 1977 SSCB Anayasasında Karma Kuvvetler Birliğinin Uygulanması ve Sorunları. HBV Hukuk Fakültesi Dergisi, C.XXV,Say1-1, S.473-510.

POPOV,L./MİGRAÇEV,Y./TİHOMİROV,S.,(2012). Gosudarstvennoe Upravlenie V Rossii i Zarubejnıh Stranah: Administrativno-Pravovze Aspektı. Moskva: İzdatelstvo Norma.

POPOV,L./MİGRAÇEV,Y./TİHOMİROV,S.,(2011). Gosudarstvennoe Upravlenie i İspolnitelnaya Vlast. Moskva: İzdatelstvo Norma.

REMINGTON, T.F.,(1999). Politics in Russia. New York: Longman.

SCHAPIRO,L.,(1970). The Goverment and Politics of the Soviet Union, London: Hutchinson University Library Press.

STAŞENKO,L./ŞAMBA,T.,(2003). İstoriya Gocudarctva i Prava Rosii. Tom.2. Moskva: İzdatelstvo Norma.

ŞEN,İ.G.,(2004). Rusya Federasyonu Siyasal Sistemi. Eskişehir:Anadolu Üniversitesi Yayınları, No:1552, Hukuk Fakültesi Yayınları, No:7.

TANİLL̇,S.,(2017). Uygarlık Tarihi, İstanbul: Cumhuriyet Yayımları.

TOWSTER,J.,(1965). The Geograpy and Historical Heritage of the U.S.S.R. Soviet Poitics and Government. New York-1965:Alfred A Knopf Publisher.

TÜRKKAYA, A.,(1961). "Sovyetler Birliği Devlet İdaresi”. A.Ü.S.B.F. Yayınları. 
Kolektif Başkanlık Teorisine Göre Yüksek Sovyet: İcra Kurulu Olarak Yüksek Sovyet Presidyumu ve Hükümet Organı Olarak Bakanlar Sovyeti

UNGER,A.,(1981). Constitutional Development in the USSR. London: Methuen Publisher.

WHITE, S.,(2000). Russia's New Politics: The Management of A Postcommunist Society. Cambridge: Cambridge University Press. 